\title{
DO BOARD CHARACTERISTICS DRIVE FIRM PERFORMANCE? AN \\ INTERNATIONAL PERSPECTIVE
}

\author{
María Consuelo Pucheta-Martínez \\ Associate Professor \\ Universidad Jaume I \\ Departamento de Finanzas y Contabilidad \\ Campus del Riu Sec, s/n \\ 12071-Castellón \\ Spain \\ Phone: 0034964387141 \\ e-mail:pucheta@uji.es \\ Isabel Gallego-Álvarez \\ Associate Professor \\ University of Salamanca \\ Multidisciplinary Institute for Enterprise (IME) \\ Department of Business Administration \\ Campus Miguel de Unamuno, Edificio FES \\ 37007-Salamanca \\ Spain \\ e-mail: igallego@usal.es
}

Corresponding author: María Consuelo Pucheta-Martínez

\section{ACKNOWLEDGEMENTS}

The authors acknowledge financial support from the Spanish Ministry of Economy, Industry and Competitiveness for the research project ECO 2017-82259-R and from the University Jaume I, Spain, for the research project UJI-B2018-15. 


\title{
DO BOARD CHARACTERISTICS DRIVE FIRM PERFORMANCE? AN INTERNATIONAL PERSPECTIVE
}

\begin{abstract}
The aim of our research is to analyze how board characteristics influence firm performance. In this paper, we specifically examine how board size, board independence, CEO duality, female directors and board compensation affect firm performance in a sample of international firms. The final panel data sample is composed of 10,314 firm-year observations belonging to 34 countries that have been grouped into six geographic zones: Africa, Asia, Europe, Latin America, North America and Oceania. Drawing on agency theory and dependence resource theory, we posit five hypotheses. The results show that some board characteristics, such as board size, board independence and having a female director, are positively associated with firm performance, whereas CEO duality, contrary to our expectations, also impacts positively on firm performance. Moreover, board compensation is not associated with firm performance. Tobin's Q was used to measure firm performance, although an accounting measure was also employed for robustness analyses and to provide more validity to our results.
\end{abstract}

Key words: Board size, board independence, CEO duality, female director, board compensation, corporate performance, international companies.

JEL codes: M14, G38 


\section{Introduction}

Corporate governance refers to the procedures and processes according to which organizations are directed and controlled by their CEO, board of directors and senior management. The literature highlights the fact that the board of directors is an important and highly effective internal mechanism of corporate governance and fulfills two important functions in companies: supervision of executive management in representation of the shareholders and providing business resources and assessment. In their supervisory role, the boards use their time and resources to monitor firm performance and the behavior of the executive managers.

The theoretical basis of the supervisory function of the board is derived from agency theory, which highlights the possible conflicts of interest that may arise from the separation of ownership and control in companies (Jensen and Meckling 1976). According to Fama and Jensen (1983), agency theory views the board of directors as an essential element of the control mechanism to ensure that the problems resulting from the principal and agent relationship are controlled. This theory is the theoretical framework adopted by most research on corporate governance (Shleifer and Vishny 1997).

In addition to this theory, and in accordance with resource dependence theory, boards of directors help companies improve their performance by reducing their dependence on the external environment and contingencies (Pfeffer and Salancik 1978). This theory maintains that the board of directors is an essential link between the firm and the external resources that a firm requires to maximize its performance (Pfeffer and Salancik 1978). According to these theories, an effective corporate governance system increases confidence in the company and therefore attracts investment and talent, which in turn can result in a better firm performance.

For $\mathrm{Hsu}$ and $\mathrm{Wu}$ (2014), interest in issues regarding board characteristics has increased in recent years due to corporate fraud, corporate misconduct, negligence and massive loss of shareholders' wealth, with corporate scandals in different multinational 
companies being especially relevant. This has made it a priority issue for both researchers and policy makers. In this sense, previous studies have documented how certain board characteristics, such as board independence (Brown and Caylor, 2006) or size (Jackling and Johl, 2009; Cheng, 2008), among others, influence firm performance. These research studies have mainly addressed a single country (e.g. Australia, Japan, UK), and therefore it is considered necessary to advance the knowledge of how certain board characteristics influence firm performance considering countries with different institutional environments.

Therefore, this paper aims to extend the debate outlined above and contribute to the existing literature in several ways. In the first place, we wished to analyze how certain board characteristics, such as board size, board independence, CEO duality, existence of female directors and board compensation or remuneration can influence firm performance and find out whether the results obtained are in line with previous findings according to the theories being taken into account: agency theory and resource dependence theory.

Secondly, previous studies have focused mainly on specific time periods and on a sample of firms operating in a specific country, such as Australia, Japan and UK (Kiel and Nicholson, 2003; Ullah ,2017; Weir and Laing, 2001; Chang et al., 2015), while a few papers, as far as we know, have drawn on a sample of several countries (e.g. Fauver et al., 2017, Claessens and Yurtoglu, 2013; Kim and Lu, 2013; Iliev et al., 2015). Our paper also employs an unbalanced panel dataset of 10,314 firm-year observations within 34 countries and 9 economic sectors for the period 2004-2015. By including firms in countries with different institutional environments, we increase the heterogeneity of the dependent variables and, therefore, also the robustness and generalization of the results. Moreover, the availability of data from several countries adds special interest to our analysis, since it allows the analysis to be extended to a broader point of reference than the corporate system addressed in most of the existing studies. In this regard, the firms in our sample can be split up between common and 
civil law countries, which have different characteristics (Fauver et al. 2017; Claessens and Yurtoglu, 2013; La Porta et al. 1998). Civil law systems are more oriented to protect the government and creditors' interests, companies get financial support from financial entities, there is a low legal protection of shareholder's rights, capital markets are less liquid and ownership is highly concentrated. In contrast, common law systems are more oriented to shareholders, companies get funding from capital market because they are more liquid and ownership is more dispersed. Furthermore, while in civil law countries the conflict of interests arise between controlling shareholders and minority shareholders, in common law countries these conflicts are between managers, including CEO, and shareholders.

In the third place, we wished to check whether board characteristics affect firm performance equally, since previous studies have shown that some of them, such as board size, have a positive effect (e.g., Jackling and Johl 2009; Guest 2009; Kiel and Nicholson 2003), while other characteristics do not maintain such an obvious relationship. Independent directors, for example, can have a significant positive influence on the value creation activities of the company and, therefore, on its performance through its strategic decisionmaking (Gabrielsson 2007). In the case of women on the board, different studies have also found a positive relationship with firm performance (e.g. Liu et al., 2013; Kılıç and Kuzey 2016; Terjesen et al., 2016). In contrast, with other board characteristics, such obvious results have not been obtained, especially in the case of CEO duality, where several authors such as Corbetta and Salvato (2004) and Song et al. (2006) obtained the opposite results to those they had raised in their hypotheses, since the hypotheses had been formulated in negative terms, whereas CEO duality was found to have a positive effect on firm performance. For board compensation and firm performance, the relationship has not always been positive. Thus, Donaldson and Davis (1991) found that board compensation was not related to firm performance. Similar results were obtained by other authors, such as Larcker et al. (2007) and 
Jeppson et al. (2009). Thus, this paper aims to extend the debate outlined above and contribute to the existing literature in several ways. First of all, we analyze how certain board characteristics, such as board size, CEO, duality, female directors and board compensation or remuneration can influence firm performance and check whether the results obtained are in line with the previous results according to the theories developed: agency theory and resource dependence theory.

In addition, a contribution is made to the supervision and control function performed by the board of directors, with agency theory and resource dependence theory being used to better understand this control function.

This paper is structured into the following sections. After the introduction, the theoretical framework and the hypotheses are presented in section two. In the third section, we present the methodology used and the sample and the variables are described. In the fourth section, the results obtained in this research are analysed and, finally, in the last section, the conclusions and the implications derived from our analysis are presented.

\section{Theoretical background and hypotheses}

The area of board characteristics and their link to firm performance has been of increasing interest in recent years. One of the most plausible explanations is based on agency theory, such that given the separation of ownership and control, corporate governance becomes a way of reducing agency costs. In this regard, agency theory (Jensen and Meckling 1976; Fama and Jensen 1983) upholds that the main goal of the principal (shareholder) is to maximize firm value and obtain maximum firm performance, and thus they delegate this task to the agent (manager), who is assumed to be rational, individualist, risk-averse and effortaverse, and therefore his or her objectives may be contrary to those of the principal. Since the structure of the board of directors (the principal) and its possible relation to firm performance 
(represented by the manager-agent) is what informs our research, it can be said that agency theory is at the foundation of the present study.

Although agency theory has been a very popular approach for previous empirical studies examining the impact of various board characteristics on firm performance, these studies have reported mixed and often contradictory results. (e.g., Hutchinson and Gul 2004; Jensen and Murphy 2004). A plausible explanation for these inconclusive results is that the agency theory-based studies have focused only on the monitoring function of the boards and ignored the resources that boards of directors provide to companies. Therefore, the application of other theories such as resource dependence theory is important.

According to resource dependence theory, boards help companies improve their performance by reducing their dependence on the external environment and contingencies (Pfeffer and Salancik 1978), thereby lowering their transaction costs, which may fundamentally assist their survival. From a resource dependence perspective, it can be similarly argued that a larger board brings greater opportunity for more links and hence access to resources. Other authors, such as Zahra and Pearce (1989), argue that when a firm designates a member to the board, it expects the directors to use their knowledge, skills and experience to provide useful counsel to the company, improve its legitimacy and reputation and support the firm's capabilities for strategic assessment and implementation (Hillman and Dalziel 2003).

Although the agency theory and dependence resource theory are accepted in the supervision, control and reputation function performed by the board of directors, there is still no unanimity as to the relationship between board characteristics and firm performance. Kiel and Nicholson (2003) state that, in general, there is a lack of consistent evidence of the relationship between board composition and firm performance, and in fact many of the results are contradictory (Kim 2005). In this regard, some authors have determined that there is a 
positive relationship between board characteristics and firm performance, while another set of papers documents a negative relationship (Abdo and Fisher, 2007). Moreover, authors such as Dalton and Dalton (2011), among others, conclude that board attributes do not influence firm performance.

From the review of the literature and individually for each of the variables, different results are obtained. Thus, for board size authors such as McIntyre et al. (2007), for companies in Canada, a positive relationship between this characteristic and firm performance is obtained, the same as Kiel and Nicholson (2003) for companies in Australia or Reddy et al. (2010) for New Zealand companies. In contrast, other studies addressing other countries obtain a negative relationship. This is the case of the works carried out by Dey and Chauhan (2009), Guest (2009) and O’Connell and Cramer (2010) for India, England and Ireland respectively.

Another board characteristic studied in previous research is board independence, where the results obtained have also been mixed. Lin et al. (2009) for companies in China, O'Connell and Cramer (2010) for companies in Ireland and Mura (2007) for companies in the UK obtain positive results. Stanwick and Stanwick (2010) for companies in Canada and Bhagat and Black (2002) for companies in United States obtain negative results and other studies found no relation, such as those carried out by Dey and Chauhan (2009), Lehn et al. (2009), Miwa and Ramseyer (2005) for companies from India, the United States and Japan, respectively. The results obtained for CEO duality have also been diverse. A positive relation is obtained by Kota and Tomar (2010) for companies in India, and Elsayed (2007) in Egypt, a negative relation was found for Nigeria (Ehikioya 2009) and Russia (Judge et al.) and no relation was obtained by Baliga and Moyer (1996) for the United States or Lin et al. (2009) for China. 
In the case of female directors, we can also find different results depending on the countries analyzed. Carter et al. (2003) found for United States companies that the proportion of women on boards has a positive influence on firm performance. The same occurs with firms in Denmark (Smith et al., 2006). However, other research conducted in Sweden (Du Rietz and Henrekson, 2000) and Norway (Randöy et al., 2006) finds that female directors do not influence firm performance, and therefore the results obtained so far are not conclusive.

As regards board compensation, Firth et al. (1995), for Norway, find a positive relationship between board compensation and firm performance and in Germany, Andreas et al. (2012) obtain a positive relationship for a sample of 928 German listed companies as well.

A review of the literature thus shows that much of the research on this topic has only taken a single country into consideration. Hence, there is importance in continuing with this line of research in the context of more than one country and proposing different hypotheses in order to advance in the determination of this relationship in the framework of the agency and resource dependence theories.

\subsection{Board size}

The first factor we analyze is board size. Board size refers to the total number of directors that can influence the corporate governance practices of companies and, as a consequence, their performance (Yermack 1996). Given that the strategic decisions of the firm are taken by the board, its characteristics can affect the decision-making process (Fodio and Oba 2012). Moreover, board size is an important dimension of the board structure (Noor and Fadzil 2013) and can be used as a proxy for the efficiency of the board of directors (Jia and Zhang 2013). In general, it may be thought that larger boards are more inefficient because agreements are more difficult to reach, owing to multiple interests (Brown et al., 2006). However, one can also consider that an increase in the number of members will bring different personal characteristics that can help to link the organization with its external 
environment and ensure critical resources, including prestige and legitimacy, since with more members, there will be a greater wealth and variety of opinions and experiences and an increase in the supervisory capacity of the board (Mintzberg 1993, Pearce and Zahra 1992).

In this regard, the agency and resource dependence approaches seem to support the idea that the larger the board, the more efficient it will be. According to agency theory (Jensen and Meckling 1976), boards with a large number of directors are considered to be more effective in handling and controlling management; therefore, in terms of the agency problem, a greater number of directors involved in management activities will make the board more vigilant. The agency theory focuses precisely on the supervisory and control function of the board of directors (Gul and Leung 2004; Hutchinson and Gul 2004; Jermias 2007; Tsui et al. 2001). Furthermore, resource dependence theory suggests that large and diversified boards are more likely to contribute the knowledge capital of the business sector in a deeper way, which can later influence the quality of strategic decision-making and, in the end, have a positive impact on performance (Arosa et al. 2010). In short, board size is an essential link between the company and the external resources that it needs to maximize its performance (Pfeffer and Salancik 1978).

Therefore, drawing on agency theory, resource dependence theory and past evidence (e.g., Jackling and Johl 2009; Guest 2009; Kiel and Nicholson 2003), it seems that there is a positive relationship between board size and firm performance. This positive relation seems to derive from the fact that when the board of directors has more members, there will be a greater wealth and variety of opinions and experiences and an increase in the supervisory capacity of the board, at the same time that more bonds will be formed between the company and its surroundings, thus facilitating the obtaining of resources that have a favourable impact on the creation of value for the company and, ultimately, on firm performance (Guest 2009). 
Other authors, such as Coles et al. (2008), also obtain a positive relationship for a sample of 8,165 firm-year observations. Their study obtains a positive association between firm performance measured by Tobin's Q and board size in the context of large companies, which indicates that a large board size helps improve the overall performance of companies. For companies listed on the Karachi Stock Exchange (Pakistan), Singh et al. (2018) also show a positive relationship between board size and firm performance.

Considering the above, Lehn et al. (2009) conclude that board size should be related to the size of the company and its growth opportunities and, therefore should not be set based on a specific size recommended by a standard. Therefore, the board must have a size suitable for facilitating decision-making and reducing the costs of its operation, guaranteeing diversity of criteria adapted to business needs (Pucheta-Martínez 2015). According to the results obtained in previous investigations, we propose the following hypothesis:

H1: Ceteris paribus, there is a positive association between board size and firm performance

\subsection{Board independence}

Independent directors are professionals without any relation to the management of the company, so they are unlikely to interfere in corporate decisions with their personal opinions (Agrawal and Knoeber, 1996). Independent directors are a relevant control mechanism for companies because they make more objective decisions than managers and shareholders and provide new points of view different from the more traditional points of view, which are more focused on financial issues (Zahra and Stanton, 1988). In fact, Ibrahim and Angelidis (1995) suggest that independent directors usually care about all stakeholders, given that most firms are less likely to retain useful information for their stakeholders. Furthermore, independent directors are more interested in guaranteeing the appropriate behaviour of firms and the fulfilment of the established goals. Thus, it is expected that independent directors will be 
more objective and independent when assessing the firms' management and behaviour than executive directors (Sonnenfeld, 1981).

In this regard, agency theory argues that boards with a high proportion of independent directors are more effective in governing, handling and controlling management (Jensen and Meckling 1976; Fama and Jensen 1983; Jizi et al. 2014; Fernández-Gago et al. 2016). In the same vein, Volonte (2015) indicates that independent directors reduce agency conflicts as they act as an effective oversight mechanism for the board and are more likely to protect the interests of shareholders. Furthermore, according to resource dependence theory, independent directors can have a significant positive influence on the value creation activities of the company and, therefore, on its performance through its strategic decision-making (Gabrielsson 2007).

Dalton et al. (1998) claim that independent directors provide experience and objectivity. Furthermore, they highlight some reasons which may justify the presence of independent directors on boards, such as (a) their implication in correcting unbalanced powers and agency problems, (b) their interest in improving the corporate governance quality of firms and in guaranteeing the social interest in the decision-making process and, finally, (c) their commitment to providing an effective monitoring role of managers.

Regarding the relationship between independent directors and firm performance, the results obtained in the previous literature shows a positive association. Dahya and McConnell (2007), who investigated the impact of board independence on firm performance for a sample of companies in the United Kingdom, find that companies that incorporate independent or external directors on their boards exhibit a significant improvement in their performance. In addition, for a sample of companies from the same country, Weir et al. (2002) found that board independence positively influences performance, measured by Tobin's Q. Other research conducted in other countries by different authors also obtains positive results in the 
relationship between independent directors and firm performance. In this sense, Coles et al. (2001) suggest with their research that a greater proportion of independent directors improves the control and strategic decision-making processes of the board through better tracking, and Ritchie (2007), Masulis et al. (2012) find a positive association when measuring the result in terms of Tobin's Q, ROE and ROA.

Hence, drawing on agency theory and resource dependence theory, a higher presence of external or independent directors can lead to a greater increase in the internal control of the company, a greater disclosure of information as well as a more effective search for actions and decisions that protect shareholders. Accordingly, we predict a positive relationship between board independence and firm performance, proposing the following hypothesis:

H2: Ceteris paribus, there is a positive association between the proportion of independent directors on boards and firm performance

\subsection{CEO duality}

CEO duality refers to the situation when the CEO also occupies the position of Chairperson (control) of the board of directors, resulting in a concentration of managerial power (Rechner and Dalton 1991; Surroca and Tribo 2008). For authors such as Jensen (1986), the concentration of power in one person increases the risk that he or she can develop strategies that favour their personal interests to the detriment of the company, since they may give rise to opportunistic actions and deplete the efficiency of the board, which would have a negative effect on business performance.

Within the frame of the agency theory (Jensen and Meckling 1976), firms should divide the roles of CEO and Chairperson to avoid a concentration of power in the hands of a single person. Considering this theory, Goyal and Park (2002) and Hashim and Devi (2009) argue that the separation of the roles of Chairperson and CEO is preferable in order to avoid a concentration of power in the hands of a single person and to provide an effective system of 
controls and balances regarding the activities and performance of executive directors. In this same regard, Fosberg and Nelson (1999) have argued that the separation of the functions of management and control within a company reduces agency costs and leads to better firm performance.

Authors such as Christensen et al. (2010), Dahya et al. (2009), Faleye (2007), Tuggle et al. (2010) and Singh et al. (2018) conclude that CEO duality is negatively associated with company profitability, since it prevents the board of directors from independently exercising its control function over management. This negative effect can also be due to the fact that duality facilitates the accumulation of power in the same person and gives rise to low-quality financial information, the manipulation of profits and the generation of opportunistic actions, as well as undermining the efficiency of the board of directors. Therefore, according to agency theory, CEO duality will negatively influence the outcome of the company, since according to this theory it is preferable to separate the roles of Chairperson and CEO to avoid a concentration of power in the hands of only one person.

Previous research conducted in specific countries such as New Zealand (Prevost et al. 2002), Canada (Bozec 2005; Jermias 2007), Hong Kong (Tsui et al. 2001) and the United States (Jermias and Gani 2014) have obtained evidence that CEO duality has a negative impact on firm performance. These results are in line with the recommendations made on corporate governance by the Business Roundtable (2012) concerning principles of corporate governance, or the Corporate Governance Code (2010) in the UK, which consider that the role of the CEO and Chairperson should be kept separate. Considering the results of previous research studies, we propose the following hypothesis:

H3: Ceteris paribus, there is a negative association between CEO duality and firm performance 


\subsection{Female directors}

Another variable that we will analyze is the presence of women on boards of directors, a topic that in recent years has acquired special relevance. The two theories that support the idea that women contribute to a more effective board and better firm performance are agency theory and the resource dependency theory.

Agency theory that postulates that female directors on boards are the ones that contribute a wider range of perspectives in decision-making, which increases the independence of the board while reducing agency costs and, as a consequence, the value of the company increases, all of which makes it one of the crucial theories used by academics to discuss the direct effect of female presence on the performance of the company (Hillman and Dalziel, 2003). In this regard, agency theory assumes that female directors can act as a mechanism of supervision and control of board activities (Adams and Ferreira, 2009). As an argument that can explain this premise, authors such as Solimene et al. (2017) argue that female directors have acquired high levels of education in recent years, such as Master's degrees and other postgraduate studies and, therefore, are considered highly professional and experienced when making important decisions on the boards of directors.

According to the resource dependency theory, female directors contribute unique and valuable resources and relationships to their boards as they are considered an essential link between the company, its environment and the external resources on which a company depends. It is a matter of capturing resources that improve the economic performance of the company thanks to the ties and contacts that female directors have with the environment (Hillman et al., 2007).

Several authors (e.g., Gul et al., 2011) have argued that women play an important role in the field of business management, since women bring to their profession values and criteria that differ from those used by men. Authors such as Seierstad (2016) consider that the role of 
female directors on boards is relevant for two reasons: one is due to the business model and the second is due to social justice. The first is based on the premise that having female directors on boards will contribute new skills that will in turn have an impact on improving firm performance; the second focuses on the need to establish heterogeneity on boards of directors in order to represent all the individuals on the teams. In this research, the first premise is the most appropriate one because we believe that women directors on boards can provide different points of view in decision-making processes compared to men, which can be very beneficial for business (Hoobler et al., 2016).

The arguments presented and the theoretical framework derived from agency theory (Jensen and Meckling 1976) and resource dependence theory seem to support the idea that a greater number of women on boards of directors will increase firm performance. The previous literature has also shown a positive effect of female directors on firm performance. For instance, in a sample of companies in the United States, Carter et al. (2003) find that the proportion of women on boards of directors has a positive influence on firm value measured by Tobin's Q, concluding that diversity has a positive effect on firm performance. Other research, by Erhardt and Werbel (2003), also conducted for US companies, found that a greater degree of board diversity is associated with higher firm performance, measured on this occasion by return on assets (ROA) and return on capital investments. In addition, Konrad et al. (2008) found that the impact of women on boards is greater when there is more than one woman present on that board. In these cases, women feel stronger together and, as such, can have a stronger voice in the decision-making process, implying that they will also feel more valued. Other research conducted by different authors also found a positive relationship (e.g. Liu et al. 2013; Kılıç and Kuzey, 2016; Terjesen et al. 2016); hence, these studies provide strong evidence that it is better to have women on the board to be able to obtain better firm 
performance. Considering the previously established arguments, we propose the following hypothesis:

H4: Ceteris paribus, there is a positive association between the presence of female directors on boards and firm performance

\subsection{Board compensation}

In recent years, board compensation or remuneration has become one of the most debated issues in the literature on board characteristics of corporate governance, especially when it comes to finding a balance between compensation systems that align the interests of principal and agent and, at the same time, distribute the risk between both figures. One of the theories on which board compensation relies is the agency theory, in that the idea is to develop a compensation package that makes it possible to attract, retain and motivate managers (Conyon 2006). Thereby providing management with an incentive toward better firm performance in such a way that it is possible to retain the manager, who is efficient or attract others who are even more efficient.

Over the years, the compensation of board members has mainly consisted of a fixed compensation and small additional supplements, such as all expenses paid for meetings. However, the difficulties of the traditional remuneration systems, both fixed and short term, fail to solve the agency problems by not avoiding the short-term opportunistic behavior of the directors and, therefore, not aligning the interests of directors and shareholders, which has meant that variable and long-term remuneration systems are increasingly being used to favor both shareholders and board members (Murphy 1999). In short, and following Jensen and Meckling (1976), the compensation programs should be designed to motivate board members to select and implement actions that increase the wealth and value of the company and, therefore, firm performance. In this regard, Magnan et al. (2010) argue that board compensation should be high enough in order to attract competent and experienced directors 
and to reward their duties. However, this remuneration should not be as high as impairing their independence, objectivity and judge. Board compensation should be determined in a transparent and objective way by considering the integration of the talent of directors and the corporate governance's philosophy of a firm, and not should base on short-term goals because it may encourage speculative behaviours contrary to the long-term targets of firms.

Diverse studies have been conducted to analyze the relationship between board compensation and firm performance. In this regard, Molonko (2004) reports that board compensation is positively associated with performance of a sample of Kenyan banks. The paper of Watson and Wilson (2005) supports the alignment role performed by board pay between managers and owners as suggested by agency theory, since their findings show that board compensation has a positive effect on firm performance. For Conyon (2006), linking board remuneration to firm performance should be considered fair for shareholders, since board members are rewarded based on their individual and firm performance. Andreas et al. (2012) provide evidence that board remuneration plays a relevant role as corporate governance mechanism, especially in companies where other corporate governance tools are weaker, by affecting positively firm performance. Consistent with this evidence, Müller et al. (2014) also show that board members well-rewarded perform better by enhancing firm performance and Handa (2018) documents that the relationship between board remuneration and bank performance is positive. Thus, based on above arguments, we posit the following hypothesis:

H5: Ceteris paribus, there is a positive association between board compensation and firm performance 


\section{Methodology, sample and variables}

\subsection{Sample}

Our initial sample consisted of 13,179 international firm-year observations from 2004 to 2015. We then excluded from this sample financial entities and companies for which all the data necessary for the analysis was not available, removing 2,865 companies in all. Thus, the final panel data sample was composed of 10,314 firm-year observations. The data (companyrelated, economic, financial and corporate governance) used in this research come from the Thomson Reuters database, an international database that collects all fundamental data in reporting entities from all countries in targeted global indices (FTSE 100 index, S\&P 500 index, Dow Jones index, NIKKEI 225 index, Euro Stoxx index, CAC 40 index, IBEX 35, NASDAQ 100 index), among others. Our sample is unbalanced because during the period explored, not all firms are observed, given that some of them delisted because of acquisitions and mergers or because they went bankrupt, among other things. Financial entities were removed because they must comply with particular accounting rules and their supervision by financial authorities is stricter. Accordingly, it is more difficult to compare the annual financial statements of financial entities with those of the non-financial firms. The companies of the sample belong to 34 countries, shown in Table 1, where the observations by country and their frequencies are also provided. According to the figures in Table 1, the countries most represented are the United States with $33.50 \%$ of the companies in the sample, Canada with $10.20 \%$, United Kingdom with $10 \%$ and Japan with $9.8 \%$. In contrast, the countries with the fewest firms in the sample are Egypt, Greece and Israel with $0.1 \%$ and Jersey and Portugal with $0.2 \%$. These countries have been classified into six big geographic areas in order to control regional effects: Africa, Asia, Europe, Latin America, North America and Oceania. By including firms in regions with different institutional environments, we increase the robustness and generalization of the results. 


\section{Insert Table 1}

Corporate governance attributes vary greatly among countries. In this regard, in Table 2 we provide some institutional dimensions, which characterise the corporate governance system of countries in our sample. Specifically, we analyse, drawing on the papers of La Porta et al. (1998) and Claessens and Yurtoglu (2013), the legal origin, the legal rights' strength, the creditors' rights, the legal protection of minority shareholders, the disclosure requirements, the shareholders' rights (one share, one vote) and the efficiency of judicial system. As appreciated in Table 2, concerning the legal origin of the countries in our sample, almost 35\% of them are located in common law systems, while $65 \%$ are domiciled in civil law systems. Additionally, the majority of common law countries in our sample tend to have, on average, strong formal legal rights, particularly some countries in Asia, Oceania, Europe, North America and South Africa, in comparison to civil law countries, where have, on average, a medium level of formal legal rights, mainly countries from European and Scandinavian contexts. Some countries form Latin America and African show weak formal rights. The creditors' rights tend to be stronger in common law countries than in civil law countries, although the differences between them are not very significant showing, on average, an intermediate level of creditors' rights. Regarding the legal protection of minority shareholders' rights, it can be appreciated that it is higher in common law systems than civil law systems, where it tends to be low. The disclosure requirements in common and civil law countries are consistent with the level of legal protection of minority shareholders' rights, except for some countries in both systems. The judicial efficiency in both common and civil law countries is similar, although it tends to be a little stronger in common law systems. Finally, it is observed in Table 2 that the shareholders' right -one share, one vote- prevails in civil law countries in contrast to common law, where it is hardly considered.

\section{Insert Table 2}


The companies in the sample operate in nine industry sectors, which are shown in Table 3. In this analysis, we used the TRBC economic sector classification supplied by Thomson Reuters. Consistent with the Global Industry Classification Standard (GICS), our industry classification is a market-based classification. As can be observed in Table 2, 20.70\% of the companies in our sample operate in the industrial sector, $18.88 \%$ in consumer cyclical, $13.25 \%$ in basic materials and $10.76 \%$ in energy. In contrast, the telecommunications services sector represents $3.82 \%$, the lowest proportion.

Insert Table 3

\subsection{Variables}

\subsubsection{Dependent variable}

In line with past research (e.g., Carter et al. 2010; Vafaei et al. 2015; Kalsie and Shrivastav 2016; Hoffman 2014; García-Ramos et al. 2017), we use Tobin's Q as proxy for calculating our dependent variable, firm performance. Most researchers who employ Tobin's Q to measure firm performance use Chung and Pruitt's (1994) approximation, which is calculated as the market value of a firm's common stock + the liquidating value of preferred stock + the book value of debt divided by the total assets (Jiang et al. 2015).

\subsubsection{Independent variables}

The first independent variable used is board size, labelled as B_SIZE and measured as the total number of board members. Board independence (B_INDEP) is the second independent variable employed, calculated as the ratio between the total number of independent members on boards and the total number of board members. The third independent variable is CEO duality (CEO_DUALITY), measured as a dummy variable that takes the value 1 when the Chairperson of the board serves simultaneously as CEO and 0 , otherwise. The presence of women directors on boards is the fourth independent variable 
considered in this analysis, denoted by FEM_DIR and computed as the ratio between the total number of female directors on boards and the total number of directors on boards. Finally, board compensation is the fifth independent variable used, labelled as B_COMPENSATION and measured as the log of board compensation, which is the total compensation paid to all board members.

\subsubsection{Control variables}

Several control variables have been taken into account. Board meetings (B_MEETING) is the first control variable considered, measured as the number of meetings held by boards every year. In line with prior research (e.g. Zhu et al. 2016; Mishra and Kapil 2018), we also expect a positive association between board meetings and firm performance. The second control variable included in the model is firm size, SIZE, calculated as the log of total assets (Kong and Kong 2017; Tyagi et al. 2018). We predict a positive effect of firm size on firm value, consistent with Palaniappan (2017a), who show that company size positively affects firm performance.

The leverage of firms has also been considered as a control variable. The leverage is denoted by LEVERAGE and is measured as the ratio between firm debt and total assets. We expect a negative effect of leverage on firm value, since firms with more debt are more likely to perform worse. Authors such as Tsuruta (2017) and Vieira (2017) provide evidence on the negative relationship between a firm's leverage and firm performance. Another control variable used is capital intensity, labelled as CAPITAL_INTENSITY and computed as the ratio between firm long-term or fixed assets and total assets. Previous research shows mixed findings about the impact of capital intensity on firm value. Jorgenson and $\mathrm{Vu}$ (2005) and Bernard and Jensen (2007) report a better firm performance when capital intensity increases, while Lee and Qu (2011) demonstrate a non-linear association, concretely quadratic, between 
capital intensity and firm value, concluding that as the capital intensity of companies increases, firm performance decreases, but beyond a certain threshold, more capital intensity results in a higher firm value. Thus, we expect that firm performance can be positively or negatively affected by capital intensity. Ownership concentration is also another control variable considered. This variable is labeled as OWNSHIP_CON and is measured as the average percentage of shares held by the three largest shareholders in the ten largest firms in each country, in line with Eklund and Desai (2013). As Maury and Pajuste (2005) and Boerkamp (2016) suggest, a high ownership concentration will negatively affect firm performance since dominant shareholders will use their decision power for their own benefit, in contrast with the interests of minority shareholders. Dual-class stocks has been also controlled, denoted by DUAL_CLASS and calculated as a dummy variable that codes the value 1 if companies have dual-class stocks (class A/B or registered/bearer shares) and 0 , otherwise. Dual-class stocks imply that firms have two different classes of stocks, which vary voting rights, dividend payments or other characteristics. We expect a negative association between dual-class shares and firm performance, consistent with Zhang (2002). Another control variable considered is the operating performance, labelled as OPERATING_PERFORM. This variable is measured as the ratio between operating income and total assets, in line with Vafeas and Theodorou (1998), who show a positive association between operating performance and firm performance. The sector in which firms operate has also been included as a control variable (Shehata et al. 2017). We use the TRBC economic sector classification supplied by Thomson Reuters. This variable is labelled as SECTORS, and is measured as a dummy variable that takes the value 1 if the firm operates in the sector analyzed and 0, otherwise. We employ the following 9 sectors: basic materials, consumer cyclical, consumer non-cyclical, energy, healthcare, industrials, technology, telecommunication services and utilities. The regional effect has been also controlled by using 
six geographic zones: Africa, Asia, Europe, Latin America, North America and Oceania. This variable is defined as REGIONS and is measured as a dummy variable that will be code 1 if the country of the sample belongs to the region explored and 0 , otherwise. Finally, year effects $\left(\mathrm{YEAR}_{\mathrm{t}}\right)$ are also controlled by considering a set of dummy variables. In Table 4, we show a description of all variables used in this research.

\section{Insert Table 4}

\subsection{Model}

Below, we provide the model estimated to check our hypotheses:

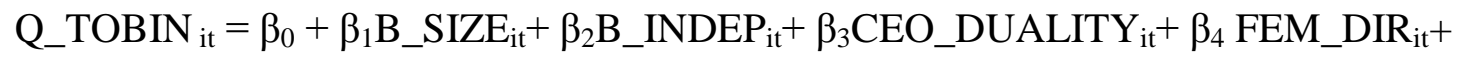

$$
\begin{aligned}
& \beta_{5} \text { B_COMPENSATION }_{i t}+\quad \beta_{6} \text { B_MEETING }{ }_{i t} \quad+\beta_{7} \text { SIZE }_{i t} \quad+\beta_{8} \text { LEVERAGE }_{i t}
\end{aligned}
$$

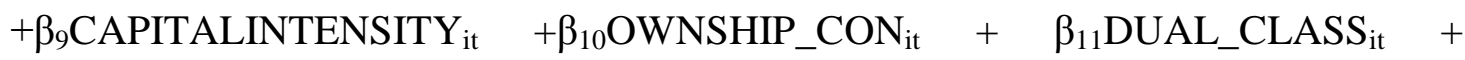

$$
\begin{aligned}
& \beta_{12} \text {OPERATING_PERFORM }_{\mathrm{it}}+\sum_{\mathrm{j}=13}{ }^{20} \beta_{\mathrm{j}} \mathrm{SECTORS}_{\mathrm{it}}++\sum_{\mathrm{j}=21}{ }^{25} \beta_{\mathrm{k}} \mathrm{REGIONS}_{\mathrm{it}}+ \\
& \sum \beta_{\mathrm{j}} \mathrm{YEAR}_{\mathrm{t}}+\mho_{\mathrm{i}}+\theta_{\mathrm{it}}
\end{aligned}
$$

Where the individual effect $\mho_{\mathrm{i}}$ represents each company, but it does vary over time, while $\theta_{\text {it }}$ differs over time among companies. Our panel data model was estimated with pooled OLS regressions with corrected (clustered) standard errors in order to control for firm-fixed effects (e.g., Rogers, 1993; Williams, 2000).

\section{Analysis of results}

\subsection{Descriptive statistics and correlations}

In Table 5, we offer the descriptive statistics of all the variables used in this analysis. As can be observed, the Q_TOBIN ratio of international firms, on average, is 0.57 (median: 0.58; minimum: 0.07 and maximum: 2.29), in line with Kiel and Nicholson (2003), who obtained a Tobin's Q value of 0.13. Board size (B_SIZE) is, on average, 10.61 board 
members, board independence (B_INDEP), on average, accounts for $63.67 \%$ and female directors (FEM_DIR) on boards represent, on average, 11.97\%. CEO_DUALITY, that is, when the Chairperson of the board serves simultaneously as CEO of the firm, on average, accounts for $32.40 \%$ and board compensation (B_COMPENSATION) is 11.69 (measured as the log of board compensation). Companies' boards (B_MEETING) meet, on average, 8.50 times every year, firm size is 9.62 (measured as the log of total assets), the average level of leverage is $13.10 \%$ and capital intensity (CAPITAL_INTENSITY) accounts for $6.35 \%$. The ownership concentration is, on average, $30.04 \%$ and the operating performance $13.74 \%$. Furthermore, $13.15 \%$ of the firms have dual-class stocks. The sector in which firms operate are: BASIC MATERIALS accounts for $13.25 \%$, CONSUMER CYCLICAL, $18.88 \%$, CONSUMER NON-CYCLICAL, 9.66\%, ENERGY, 10.76\%, HEALTHCARE, 7.99\%, INDUSTRIALS, 20.70\%, TECHNOLOGY, 8.58\%, TELECOMMNUCIATION SERVICES, $3.82 \%$ and UTILITIES account for $6.32 \%$. Finally, $0.70 \%$ of the countries of the sample are located in Africa, $15.31 \%$ in Asia, 30.70\% in Europe, $2.49 \%$ in Latin America, $43.74 \%$ in North America and $7.07 \%$ in Oceania.

\section{Insert Table 5}

In Table 6, we show the correlation matrix in order to check whether there are multicollinearity concerns. According to the figures provided in Table 6, none of the correlation coefficients are greater than 0.80 . As a result, we can confirm that multicollinearity is not a problem in our analysis.

\section{Insert Table 6}

\subsection{Multivariate analysis}

In Table 7, we provide the findings of all models estimated. In Model 1, we analyse how board size affects firm performance, in Models 2 and 3, we examine the effect of board independence and CEO duality, respectively, on firm value and, finally, in Models 4 and 5, 
we explore the impact of women directors on boards and board compensation on firm performance, respectively. In Model 6, we show the finding for all independent variables estimated in one model.

\section{Insert Table 7}

In Model 1, the variable board size (B_SIZE) has the expected sign and is statistically significant. Therefore, the first hypothesis is accepted, suggesting that board size in our sample of international firms has a positive effect on firm performance. In this regard, larger boards are more likely to enhance firm value. Our findings are consistent with Bhatt and Bhattacharya (2015) and Kalsie and Shrivastav (2016), who also demonstrate a positive association between board size and firm value. This evidence shows that board size in fact matters for companies since larger boards will positively affect firm value and, therefore, it will imply a higher wealth for shareholders. Boards with a high number of directors will provide human and social capital to the board, given that they might bring diverse past expertise, skills and professional backgrounds, as well as the knowledge of similar industries. This will be beneficial for the decision-making process. Additionally, it will be more complicated for CEOs or managers to pressure directors on a larger board. Thus, board size plays a significant role in supervising the management team and giving advice and counsel, in line with Klein (1998) or Singh et al. (2018), and this will have a positive impact on firm performance.

Model 2 explores how board independence affects firm value. The variable proportion of independent directors on boards provides a positive sign, as expected, and is significant. As a result, the second hypothesis is accepted. This finding suggests that board independence is positively associated with firm performance. Authors such as Mak and Kusnadi (2005), Palaniappan (2017b) and Palmberg (2015), among others, also find that the presence of independent directors on boards influences firm value. Our evidence shows that independent 
directors on boards may perform a relevant monitoring role by mitigating the power that managers and CEOs might have on the whole board because they are outsiders, external or non-executive directors. Independent directors usually defend the rights of shareholders, particularly minorities, given that they tend to be independent from managers and can better supervise them. In this regard, and according to Hanniffa and Cooke (2002), independent directors "are seen as a checks and balances" tool in improving board efficiency. Independent directors will be more likely to align shareholders and managers' interests and needs. Fama and Jensen (1983) argue the importance of the role performed by independent directors, because they these directors are available to provide valuable experience and professional background as well as ties or connections with external organizations, positively affecting corporate value. Thus, board independence will improve firm performance and safeguard shareholders' wealth, interests and demands (Gabrielsson, 2007).

In Model 3, we analyse the relationship between CEO duality and firm value. The variable CEO duality (CEO_DUALITY) shows a positive sign, contrary to our expectations, and is statistically significant. Hence, according to this finding, the third hypothesis has to be rejected. This evidence suggests that when the roles of Chairperson of the board and CEO of the company are combined, firm value is enhanced, in contrast with the findings of most past research (e.g., Jermias, 2007; Jermias and Gani, 2014), which reports that CEO duality results in poorer firm performance. Miller and Yang (2015), however, also show that CEO duality has a positive effect on corporate value. The arguments defining this positive relationship are centered on the fact that when the CEO and the Chairperson are the same person, power and control will be unified, thus avoiding the confusion of having two public spokespersons in the company, while the transmission of information will be improved and the coordination costs reduced, thus improving firm performance (Corbetta and Salvato 2004; Song et al. 2006). CEO duality implies a clear and higher authority in firms, which may drive companies to the 
same strategic direction addressing conflicts and lack of coordination between senior managers and stakeholders, mainly shareholders. This will result in a more efficient decisionmaking process and could lead to greater firm performance. The concentration of power in the CEO might be beneficial for firms to survive and be successful, in that the leadership will be more effective and have more legitimacy (e.g., Dalton et al. 1998). The positive impact of CEO duality on firm performance may also be explained by the fact that CEOs have specific knowledge of the firm, accumulating a lot of the firm's internal knowledge and the knowledge of the uncertain environment and context in which firms operate, in addition to being aware of the competitive advantages and disadvantages of the firm and its competitors, since they daily manage firms. This could lead to better firm performance.

Model 4 examines the relationship between board gender diversity and firm performance. The variable proportion of female directors on boards (FEM_DIR) offers a positive sign, as predicted, and is significant and, therefore, the fourth hypothesis has to be accepted. This result shows that the presence of women directors on boards is positively associated with firm value (e.g. Liu et al., 2013; Kılıç and Kuzey, 2016; Terjesen et al., 2016), hence these studies provide solid evidence that having women on the board can lead to better firm performance.

Our finding suggests that the incorporation of a minority group on boards, such as female directors, may help represent and protect shareholders' demands and interests (Webb 2004) by showing objective and critical judgments in the decision-making process, which might result in a higher firm performance. Better firm performance can also be due to the greater board independence that female directors on boards provide since directors with more conventional backgrounds do not usually raise the questions that may come from directors of a different ethnicity, cultural background or gender, as Carter et al. (2003) argue. Likewise, females on boards may contribute a diversity of opinions and views to board discussions, 
leading to more responsive policies, increasing more involvement in the decision-making process and encouraging more democratic decisions (Nielsen and Huse 2010; Webb 2004). All these qualities of female behaviour may also align the interests of all shareholders and, as a consequence, it can be assumed that female directors may help to avoid conflicts and make decisions that benefit shareholders, which might enhance corporate value.

Finally, in Model 5, we analyze the impact of board compensation on firm value. The variable board compensation (B_COMPENSATION) shows a positive sign, in line with our predictions, but it is insignificant. According to this result, the fifth hypothesis has to be rejected, suggesting that well-paid board members do not have any effect on corporate value. In other words, board members with higher compensation will not have more incentives to monitor managers, which suggests that well-rewarded board members will not result in more supervising efforts and will not be more likely to converge their interests with those of shareholders. Our evidence does not support the agent-principal or agency approach, which argues the positive effect of board remuneration on company value.

Model 6, where all independent variables are jointly estimated, reports the same results as all the independent variables are individually estimated. Thus, we reach the same conclusion both when independent variables are individually estimated, and when they are jointly estimated.

Regarding the control variables, board meetings, size and capital intensity show the expected sign and are statistically significant. Thus, large firms whose boards tend to meet several times each year are positively correlated with firm value, while increases in capital intensity reduce firm performance. Furthermore, firms operating in countries characterized by high ownership concentration underperform. Contrary to our predictions, firms with high levels of operating performance also tend to reduce firm performance. Additionally, all the sectors analyzed exhibit a negative sign and are statistically significant, showing that firms 
operating in all the sectors are more likely to underperform. The previous evidence regarding the repercussion of sector of activity on firm performance is not conclusive. In this regard, Jermias and Gani (2014), for a sample of US companies that they obtained from Compustat S \& P 500, conclude that the activity sectors do not have an effect when analyzing the impact of board characteristics on firm performance. For Spanish companies, within the context of the influence of corporate governance on firm performance as well, Pucheta-Martínez (2015) obtains a negative but not significant relationship for some sectors, and a negative and significant relationship for others, such as the oil and energy sectors. Concerning the geographic zone, our findings show that firms operating in Europe and Latin America perform better, and in Oceania worse, in contrast to companies operating in North America. Moreover, firms operating in Asia with large boards and well-paid directors tend to perform worse than companies operating in North America. Finally, the remainder of the control variables are not significant.

Additionally, endogeneity concerns have been also addressed. Although it is expected that board attributes (board size, board independence, CEO duality, board gender diversity and board compensation) affect firm value, it is also possible that over-performing companies will make up boards with certain characteristics regarding the board attributes explored in this analysis. To check for endogeneity, we estimated our models by lagging the independent variables, consistent with Ozkan (2007), who supports the idea that endogeneity problems might be reduced by lagging explanatory variables (independent variables). Our results, provide in Table 8, are in line with the findings shown in our base models when the independent variables are individually estimated. However, when all independent variables are jointly estimated, the board compensation variable exhibits a negative sign, contrary to our predictions, and is statistically significant, in comparison to the finding presented in Table 7, where it was insignificant. 
Insert Table 8

\subsection{Robustness analysis}

We have conducted a robustness check in order to assess if our findings change in the presence of an alternative measure for firm performance. Concretely, we use as proxy variable for firm performance the ROE ratio (return on equity), measured as the ratio of net profit over total equity, following Matolcsy and Wright (2011) and Li et al. (2015). In Table 9, we offer the results of all our models, namely, estimating all independent variables individually and all together in one model. As can be appreciated, the findings corroborate the result of our baseline models. In addition, the board compensation variable shows a positive sign, as expected, and is significant, both when all independent variables are individually and jointly estimated, while in our baseline model, it was insignificant. Thus, ROE can be considered a robust measure for firm performance since it not only supports our core findings, but also the sign and significance of the board compensation variable.

Insert Table 9

\section{Concluding remarks}

In this research, we aim at exploring the relationship between certain corporate governance mechanisms and firm performance. Particularly, we analyze how board size, board independence, CEO duality, board gender diversity and board compensation affect firm performance using a sample of international firms. Drawing on agency and resource dependence theories, we hypothesized that all these board attributes are positively correlated with firm value, except CEO duality, for which we predicted a negative effect.

Our findings report, as expected, that large boards with a high presence of independent and female directors tend to increase firm value, supporting agency and resource dependence approaches, and in line with the monitoring or supervising hypothesis. On the other hand, the results show that CEO duality, contrary to our predictions, has a positive impact on firm 
performance, and board compensation does not affect firm performance, also in contrast to our expectations. Thus, our evidence supports all the hypotheses posited, except those relating to CEO duality and board compensation. Certain board attributes, such as board size, board independence and board gender diversity are more likely to improve shareholder wealth and thus, shareholders might take them into account, especially potential investors. CEO duality implies a concentration of power in the CEO and, as a consequence, it was hypothesized that CEO duality might have a negative effect on firm performance since CEOs will be more interested in satisfying their needs and interests at the expense of shareholders' interests. However, our results are not consistent with this idea and CEOs can make an effort to enhance corporate value, given that this may be beneficial for their success, legitimation and reputation, among other things.

This research has several implications. Firstly, the findings of this investigation focused on a sample of international firms suggest that particular board attributes such as board size, independent directors, CEO duality, female directors and board remuneration are relevant corporate governance mechanisms for improving firm performance. Thus, this evidence may be useful for managers who are willing to enhance their reputation and to gain legitimation by shareholders, stakeholders and society. Practitioners with a shareholders' orientation should make up boards with these effective corporate governance mechanisms because they will be more likely to over perform firms. Secondly, our results also support the thesis that CEO duality does not always have a negative effect on business decisions, particularly firm performance. Therefore, this evidence should lead policymakers to consider the possibility of not reinforcing the separation of the figure of CEO and Chairperson of the board. Regulatory bodies have established recommendations or laws supporting the thesis of the positive benefits of different individuals holding the positions of CEO and Chairperson of the board, but our findings are contrary to this idea, since CEO duality improves firm 
performance. Perhaps, it would be more prudent to assess the impact of CEO duality for each business decision in particular, and according to this evidence, regulate in a more precise way the dual role of Chairperson of the board and CEO. Thirdly, current shareholders and potential investors may benefit from our findings because they could be useful for making decisions about investments and about the most appropriate board structure for increasing corporate value. Most shareholders and potential investors are interested in increasing the probability of a return on their investments, in the short or long term, depending on their orientations and, therefore, they will be willing to form boards, which encourage better firm value. Finally, the findings of this study also suggest that more research is needed. Researchers may extend our study by examining the association between other corporate governance mechanisms and firm performance, which will be useful in shedding new light on what board composition or board structure is most suitable to make a well-performing company.

This research also is subject to several limitations. Firstly, it is possible that we have disregarded some factors that potentially affect firm performance, according to prior theoretical and empirical evidence. Secondly, we have explored all countries for which it has been possible to collect all data necessary for conducting this research. Future research extending the sample scope to more countries should be carried out. Finally, we use as dependent variable a market performance measure (Tobin's Q), which limits this study to the scope of listed companies. This analysis may be extended to non-listed firms, particularly small and medium-sized enterprises, using other performance measures different from market ones.

Future lines of research can be derived from this investigation. Firstly, it would be interesting to analyze the association between board attributes and firm value, differentiating between developing and emerging countries. Secondly, we would also encourage scholars to 
explore which corporate governance mechanisms are most significant for enhancing corporate value in the banking industry, since our sample excludes this sector.

\section{Conflict of interests and funding}

The author(s) declare no potential conflicts of interest with respect to the research, authorship, and/or publication of this article.

\section{References}

Abdo A, Fisher G (2007). The impact of reported corporate governance disclosure on the financial performance of companies listed on the JSE. Inv Anal Jour 66: 43-56.

Adams R, Ferreira D (2009). Women in the boardroom and their impact on governance and performance. J of Finan Econ, 94 (2): 291-309.

Agrawal A, Knoeber C (1996). Firm performance and mechanisms to control agency problems between managers and shareholders. J of Finan and Quant Anal 31(3): 377397.

Andreas J, Rapp MS, Wolf M (2012). Determinants of director compensation in two-tier systems: evidence from German panel data. Rev Manag Sci 6:33-79.

Arosa B, Iturralde T, Naseda A (2010). Outsiders on the board of directors and firm performance: evidence from Spanish non-listed family firms, J of Fam Bus Strat 1: $236-245$.

Baliga BR, Moyer C (1996). CEO Duality and Firm Performance. What's the fuss? Strat Manage J 17(1): 41-53.

Bernard A B, Jensen J B (2007). Firm Structure, Multinationals, and Manufacturing Plant Deaths. The Rev of Econ and Statis 89 (2): 193-204.

Bhagat S, Black B (2002). The non-correlation between board independence and long-term firm performance. Jour of Corpor Law 27(2): 231-273.

Bhatt R R, Bhattacharya S (2015). Board structure and firm performance in Indian IT firms. J of Advan in Manag Res 12(3): 232-248.

Boerkamp E (2016). Ownership concentration, ownership identity and firm performance: An empirical analysis of Dutch listed firms. Paper presented at the $7^{\text {th }}$ IBA Bacheloer Thesis Conference, July, University of Twente, The Faculty of Behavioural, Management and Social sciences, The Netherlands. 
Bozec R (2005). Board of directors, market discipline and firm performance. J of Bus Finan and Acc 32(9-10): 1921-1960.

Brown LD, Caylor ML (2006). Corporate governance and firm valuation. J of Acc and Pub Pol 25: 409-434.

Brown W, Helland E, Smith JK (2006). Corporate philanthropic practices. J of Cor Financ 12: $855-877$.

Business Roundtable. (2012). Principles of corporate governance. Washington D.C: The Business Roundtable.

Carter DA, Simkins B J, Simpson WG (2003). Corporate Governance, Board Diversity and Firm Value. The Finan Revi 38: 33-35.

Carter DA, D'Souza F, Simkins BJ, Simpson WG (2010). The gender and ethnic diversity of US boards and board committees and firm financial performance. Corpo Gover: An Interna Revi, 18(5): 396-414.

Claessens S, Yurtoglu BB (2013). Corporate governance in emerging markets: A survey. Emerg. Mark. Rev 15: 1-33.

Coles JL, Daniel ND, Naveen L (2008). Boards: Does one size fit all?. J of Finan Econ 87(2): 329-356.

Coles JW, McWilliams L, Sen N (2001). An examination of the relationship of governance mechanisms to performance. J of Manag 27: 23-50.

Conyon M (2006). Executive Compensation and Incentives. Acad of Manag Persp 20: 25-44.

Corbetta G, Salvato C (2004). The board of directors in family firms: One size fitsall? Fam Busin Rev 17(2): 119-134.

Corporate Governance Code. (2010). London, the U.K. The Financial Reporting Council.

Chang ChS, Yu SW, Hung ChH (2015). Firm risk and performance: the role of corporate governance. Rev of Mana Scien 9: 141-173.

Cheng S (2008). Board size and the variability of corporate performance. J of Finan Econ 87: $157-176$.

Christensen J, Kent P, Stewart J (2010). Corporate governance and company performance in Australia. Austr Acc Rev 20 (4): 372-386.

DahyavJ, McConnell JJ (2007). Board composition, corporate performance and the Cadbury committee recommendation. J of Finan and Quant Anal 42(3): 535-564.

Dahya J, García LG, van Bommel J (2009). One man two hats: What's all the commotion. Finan Rev 44 (2):179-212. 
Dalton DR, Dalton CM (2011). Integration of micro and macro studies in governance research: CEO duality, board composition, and financial performance. J of Manag 37(2): 404-411.

Dalton D R, Daily C M, Ellstrand A E, Johnson J L (1998). Meta-analytic reviews of board composition, leadership structure and financial performance. Str Mang Jour, 19: 269290.

Dey DK, Chauhan YK (2009). Board composition and performance in Indian firms: A comparison. IUP J of Corp Gover 8(2): 7-19.

Donaldson L. Davis JH (1991). Stewardship Theory or Agency Theory: CEO Governance and Shareholder Returns. Austr J of Manag 16: 49-64.

Du Rietz A, Henrekson M (2000). Testing the Female Underperformance Hypothesis, Sm Busi Econ 1: 1-10

Ehikioya BI (2009). Corporate governance structure and firm performance in developing economies: evidence from Nigeria. Corpo Gover 9(3): 231-243.

Elsayed K (2007). Does CEO duality really affect corporate performance?. Corpo Gover: An Interna Revi, 15(6): 1203-1214.

Eklund JE, Desai S (2013). Ownwership and allocation of capital: Evidence from 44 countries. Working paper. Series from Swedish Entrepreneurship Forum, Sweden.

Erhardt N L, Werbel JD (2003). Board of Director Diversity and Firm Financial Performance. Corp Gover: An Inter Rev 11: 102-111.

Faleye O (2007). Does one hat fit all? The case of corporate leadership structure. J of Manag and Gover 11: 239-259.

Fama EF, Jensen MC (1983). Separation of ownership and control. J of Law and Econ 26 (2): $301-325$.

Fauver L, Hung M, Li X, Taboada AG (2017). Board reforms and firm value: Worldwide evidence. J. of Finan. Econ 125(1): 120-142.

Fernández-Gago R, Cabeza-García L, Nieto M (2016). Corporate social responsibility, board of directors, and firm performance: an analysis of their relationships. Rev Manag Sci 10: $85-104$.

Firth M, Lohne JC, Ropstad R, Sjo J (1995) Managerial Compensation in Norway, J of Multin Finan Mana 5(2/3): 87-101.

Fodio MI, Oba VC (2012). Gender diversity in the boardroom and corporate philanthropy: Evidence from Nigeria. Res J of Financ and Accoun 3(8): 63-69. 
Fosberg RH, Nelson MR (1999). Leadership structure and firmper formance. Intern Rev of Finan Anal 8: 83-96.

Gabrielsson J (2007). Correlates of board empowerment in small companies, Entrepr Theo and Prac 31: 687-711.

García-Ramos R, Díaz-Díaz B, García-Olalla M (2017). Independent directors, large shareholders and firm performance: the generational stage of family businesses and the socioemotional wealth approach. Rev Manag Sci 11:119-156.

Goyal VK, Park CW (2002). Board leadership structure and CEO turnover. J of Corp Finan 8: 49-66.

Guest P M (2009). The impact of board size on firm performance: evidence from the U.K. The Eur J of Finan 15(4): 385-404.

Gul FA, Leung S (2004). Board leadership, outside directors' expertise, and voluntary corporate disclosures. J of Acc and Publ Poli 23: 351-379.

Gul F, Srinidhi B, Ng A (2011). Does board gender diversity improve the informativeness of stock prices?. J of Acc and Econ 51: 314-338.

Haniffa RM, Cooke TE (2002). Culture, corporate governance and disclosure in Malaysian corporations. Abac 38(3): 317-349.

Handa R. (2018). Does corporate governance affect financial performance: A study of select Indian banks. Asia Econom and Finan Rev, 8(4), 478-486.

Hashim AH, Devi S. (2009). Board characteristics, ownership structure and earnings quality: Malaysian evidence. Res in Acc in Emer Econ 8: 97-123.

Hillman AJ, Dalziel Th (2003). Board of directors and firm performance: Integrating agency and resource dependence perspectives. Acad of Manag Rev 28 (3): 383-396.

Hillman A J, Shropshire C, Canella A A (2007). Organizational predictors of women on corporate boards. Acad Manag J 50(4): 941-952.

Hoobler JM, Masterson CR, Nkomo SM, Michel EJ (2016). The business case for women leaders: Meta-analysis, research critique, and path forward. Paper presented at Closing the Gender Gap: Advancing Leadership and Organizations. DOI: $10.5703 / 1288284316077$.

Hsu H H, Wu CYH (2014). Board composition, grey directors and corporate failure in the UK. Bri Acc Rev 46: 215-227.

Hutchinson M, Gul FA (2004). Investment opportunity set, corporate governance practices and firm performance. J of Corp Finan 182: 1-20. 
Ibrahim NA, Angelidis, JP. (1995). The corporate social responsiveness orientation of board members: Are there differences between inside and outside directors?. J. of Busin. Eth.14 (5): 405-410.

Iliev P, Lins K V, Miller D P, Roth L (2015). Shareholder voting and corporate governance around the world. Rev. of Finan. Stud 28(8): 2167-2202.

Jackling B, Johl S (2009). Board structure and firm performance: Evidence fromIndia's top companies. Corp Gover: An Intern Rev 17(4): 492-509.

Jensen MC (1986). The agency costs of free cash flow. Amer Econ Rev-Papers and Proceedings, 76: 326-329.

Jensen MC, Meckling WH (1976). Theory of the firm: Managerial behaviour, agency costs and ownership structure. J of Finan Econ 3: 305-360.

Jensen MC, Murphy K J (2004). Remuneration: Where we've been, how we got to here, what are the problems, and how to fix them. In Working paper series in finance. European Corporate Governance Institute. www.ecgi.or/wp.

Jeppson T, Smith W, Stone R (2009). CEO Compensation and Firm Performance: Is there any Relationship? J of Bus Econ Res 7: 81-94.

Jermias J (2007). The effects of corporate governance on the relationship between innovative efforts and performance. Eur Acc Rev 16(4): 827-854.

Jermias J, Gani L (2014). The impact of board capital and board characteristics on firm performance. The Brit Acc Rev 46: 135-153.

Jia M, Zhang Z (2013). Managerial ownership and corporate social performance: Evidence from privately owned chinese firms' response to the Sichuan earthquake. Corp Soc Resp and Envir Manag 20: 257-274.

Jiang H, Habib A, Gong R (2015). Business cycle and management earnings forecasts. Abac 51(2): 279-310.

Jizi M, Salama A, Dixon R, Stratling R (2014). Corporate governance and the content of corporate social responsibility disclosure. J of Bus Eth 125(4): 601-615.

Jorgenson D, Vu KH. (2005). Information Technology and the World Economy. Scandin J of Econ 107 (4): 631-650.

Judge WQ, Naoumova I, Koutzevol N (2003). Corporate governance and firm performance in Russia: An empirical study. J of World Busi 38(4): 385-396.

Kalsie A, Shrivastav SM (2016). Analysis of board size and firm performance: Evidence from NSE companies using panel data approach. Ind J of Corp Gover 9 (2): 148-172. 
Kiel GC, Nicholson GJ (2003). Board Composition and Corporate Performance: How the Australian experience informs contrasting theories of corporate governance. Corp Gover: An Inter Rev 11(3): 189-205.

Kılıç M, Kuzey C (2016). The effect of board gender diversity on firm performance: evidence from Turkey. Gend in Manag: An Intern J 31(7): 434-455.

Kim Y (2005). Board network characteristics and firm performance in Korea. Corp Gover: An Inter Rev 13: 613-631.

Kim EH, Lu Y (2013). Corporate governance reforms around the world and cross-border acquisitions. J. of Corp. Finan 22:236-253.

Klein A (1998). Firm Performance and Board Committee Structure. The J of Law and Econ 41: 275-304.

Kong G, Kong D (2017). Corporate governance, human capital, and productivity: evidence from Chinese non-listed. Appl Econ 49 (27): 2655-2668.

Konrad AM, Kramer VW, Erkut S (2008). Critical Mass: The Impact of Three or More Women on Corporate Boards. Organ Dyn 37 (2): 145-164.

Kota H B, Tomar S (2010). Corporate governance practices in Indian firms. J of Manage and Organiza 16(2): 266-279.

La Porta R, Lopez-de-Silanes F, Shleifer A, Vishny R (1998). Law and finance. J. of Polit. Econ. 106: 1113-1155.

Larcker DF, Scott A, Richardson SA, Tuna I (2007). Corporate Governance, Accounting Outcomes, and Organizational Performance. The Acco Rev 82 (4): 963-1008.

Lee S, Qu X (2011). An examination of the curvilinear relationship between capital intensity and firm performance for publicly traded US hotels and restaurants. Intern $\mathrm{J}$ of Contem Hosp Manag 23(6): 862-880.

Lehn K M, Patro S, Zhao M (2009). Determinants of the size and composition of US Corporate Boards: 1935-2000. Finan Manag 38(4): 747-780.

Lin C, Ma Y, Su D (2009). Corporate governance and firm efficiency: Evidence from China's publicly listed firms. Manag and Decis Econ 30(3): 193-209.

Liu Y, Wei Z, Xie F (2013). Do women directors improve firm value in China?. J of Corp Finan 46: 1-16.

Li M-YL, Yang T-H, Yu S-E (2015). CEO stock-based incentive compensation and firm performance: A quantile regression approach. J of Intern Finan Manag \& Acc, 26(1): 39-71.

Mak YT, Kusnadi Y (2005). Size really matters: further evidence on the negative relationship between board size and firm value. Pac-Bas Finan J 13(3): 301-318. 
Magnan M, St-Onge S, Gélinas P (2010). Director compensation and firm value: A research synthesis. Intern. J of Disclos and Gover, 7 (1): 28-41.

Matolcsy Z, Wright A (2011). CEO Compensation Structure and Firm Performance. Acc and Finan 51(3): 745-763.

Masulis RW, Wang C, Xie F (2012). Globalizing the boardroom - the effects of foreign directors on corporate governance and firm performance. J of Acc and Finan 53: 527664.

Maury B, Pajuste A (2005). Multiple large shareholders and firm value. J of Bank and Finan 29(7):1813-1834.

McIntyre ML, Murphy SA, Mitchell P (2007). The top team: Examining board composition and firm performance. Corp Gover 7(5): 547-561.

Miller S, Yang T (2015). Board leadership structure of publicly-traded insurance companies. J of Insur Iss 38(2): 184-232.

Mintzberg H (1993). Structure in fives: Designing effective organizations. Prentice-Hall, Inc.

Mishra RK, Kapil S (2018). Board characteristics and firm value for Indian companies. J of Ind Bus Res 10(1): 2-32.

Miwa Y, Ramseyer M (2005). Who appoints them, what do they do? Evidence on outside directors from Japan. J of Econ and Manag Strate 14(2): 299-337.

Molonko, L.K. (2004). Board structure, board compensation and firm profitability. Evidence from the banking industry. Research project for the Degree of Master of Business Administration. Faculty of Commerce, University of Nairobi, Kenya.

Müller V, Ienciu I, Bonaci C G, Filip, C I (2014). Board characteristics best practices and financial performance. Evidence from the European capital market. Amfite Econom, 16(36), 672-683

Mura R (2007). Firm performance: Do non-executive directors have minds of their own? Evidence from UK panel data. Finan Manag 36(3): 81-112.

Murphy K (1999). Executive Compensation. O. Ashenfelter y D. Cars (ed.) Handbook of Labor Economics 3B. Amsterdam: North-Hollan, pp. 2485-2563.

Nielsen S, Huse M (2010). The contribution of women on Boards of Directors: Going beyond the Surface. Corp Gover: An Intern Rev 18(2): 136-148.

Noor MA, Fadzil FH (2013). Board characteristics and performance from perspective of governance code in Malaysia. Wor Rev of Bus Res 3: 191-206.

O'Connell V, Cramer N (2010). The relationship between firm performance and board characteristics in Ireland. Europ Manag J 28(5): 387-399. 
Ozkan N (2007). Do corporate governance mechanisms influence CEO compensation?. An empirical investigation of UK companies. J of Mult Finan Manag 17(5): 349-364.

Palaniappan G (2017a). Board characteristics relating to firm performance: A study on manufacturing firms in India. J of Comm and Acc Res 6(1): 26-36.

Palaniappan G (2017b). Determinants of corporate financial performance relating to board characteristics of corporate governance in Indian manufacturing industry: An empirical study. Europ J of Manag and Bus Econ 26 (1): 67-85

Palmberg J (2015). The performance effect of corporate board of directors. Eur J of Law and Econ 40(2): 273-292.

Pearce J, Zahra S (1992). Board composition from a strategic contingency perspective. J of Manag Stud 29: 411-438.

Pfeffer J, Salancik G (1978). The External Control of Organizations: A Resource Dependency Perspective. New York, NY: Harper and Row.

Prevost AK, Rao RP, Hossain M (2002). Board composition in New Zealand: an agency perspective. J of Bus Finan and Acc 29(5-6): 731-760.

Pucheta-Martínez MC (2015). El papel del Consejo de Administración en la creación de valor en la empresa. Span Acc Rev 18 (2): 148-161.

Rogers, W. (1993). Regression standard errors in clustered samples. Stata Tech Bullet, 13: 1923.

Randöy T, Thomsen S, Oxelheim L (2006). A Nordic perspective on corporate board diversity, Nordic Innovation Centre, Norway.

Rechner PL, Dalton DR (1991). CEO duality and organizational performance: A longitudinal analysis. Strat Manag J 12: 155-160.

Reddy K, Locke S, Scrimgeour F (2010). The efficacy of principle-based corporate governance practices and firm financial performance: An empirical investigation. International J of Manag Finan 6(3): 190-219.

Ritchie T (2007). Independent directors: magic bullet or Band-Aid?, Corporate Governance eJournal. Available at http://epublications.bond.edu.au/cgej/5. (acceded June 2017).

Hoffmann SP. (2014). Internal corporate governance mechanisms as drivers of firm value: panel data evidence for Chilean firms. Rev of Manag Sci 8: 575-604.

Seierstad C (2016). Beyond the Business Case: The Need for Both Utility and Justice Rationales for Increasing the Share of Women on Boards. Corp Gover: An Intern Rev 24 (4): 390-405. 
Shehata N, Salhin A, El-Helaly M (2017). Board diversity and firm performance: evidence from the U.K. SMEs. Appl Econ 49 (48): 4817-4832.

Shleifer A, Vishny R (1997) A survey of corporate governance. J Financ 52:737-783.

Singh S, Tabassum N, Darwish K, Batsakis G (2018). Corporate Governance and Tobin's $Q$ as a Measure of Organizational Performance. Brit J of Manag 29: 171-190.

Smith N, Smith V, Verner M (2006). Do women in top management affect firm performance? A panel study of 2,500 Danish firms. Inter J of Perfor Manag 55: 569-593.

Solimene S, Coluccia D, Fontana S (2017). Gender diversity on corporate boards: an empirical investigation of Italian listed companies. Palgr Commun 3: 1-7.

Song F, Yuan P, Gao F (2006). Does large state shareholder affect the governance of Chinese board of directors? Working paper, Tsinghua University.

Sonnenfeld J (1981). Executive apologies for price fixing: Role biased perceptions of causality. Acade of Manag J 24 (1): 192-198.

Stanwick PA, Stanwick SD (2010). The relationship between corporate governance and financial performance: An empirical study of Canadian firms. The Bus Rev 16(2): 3541.

Surroca J, Tribo JA (2008). Managerial entrenchment and corporate social performance. J of Bus Finan and Acc 35: 748-89.

Terjesen S, Couto EB, Francisco P M (2016). Does the presence of independent and female directors impact firm performance? A multi-country study of board diversity. $\mathrm{J}$ of Manag Gover 20 (3): 447-483.

Tsui JSL, Jaggi B, Gul FA (2001). CEO domination, growth opportunities, and their impact on audit fees. J of Acc Aud and Finan 16(3): 189-208.

Tsuruta D (2017). Variance of firm performance and leverage of small businesses. J of Sm Bus Manag 55(3): 404-429.

Tuggle CS, Simon DG, Reutzel CR, Biernmen L (2010). Commanding Board of Director attention: Investigating how organization performance and CEO duality affect Board members. Attention to monitoring. Strat Manag J 31(9): 946-968.

Tyagi SH, Nauriyal DK, Gulat R (2018). Firm level R\&D intensity: evidence from Indian drugs and pharmaceutical industry. Rev Manag Sci 12:167-202.

Ullah W (2017). Evolving corporate governance and firms performance: evidence from Japanese firms, Econ of Gover 18: 1-33

Vafeas, N., Theodorou, E. (1998). The relationship between board structure and firm performance in the UK. British Accounting Review, 30, 383-407. 
Vafei A, Ahmed K, Mather P (2015). Board diversity and financial performance in the top 500 Australian firms. Austr Acc Rev: 25(4), 413-427.

Vieira ES (2017). Debt policy and firm performance of family firms: The impact of economic adversity. Intern J of Man Finan 13(3): 267-286.

Volonte C (2015). Boards: independent and committed directors?. Intern Rev of Law and Econ 41: 25-37.

Watson R., Wilson N. (2005). Board pay and the separation of ownership from control in U.K. SMEs. Smal Busin Econom, 24(5): 465-476.

Webb E (2004). An examination of socially responsible firms' board structure. J of Manag and Govern 8: 255-277.

Weir C, Laing D, McKnight PJ (2002). Internal and external governance mechanisms: their impact on the performance of large U.K. public companies. J of Bus Finan and Acc 29 (5-6): 579-611.

Weir C, Laing D (2001) Governance Structures, Director Independence and Corporate Performance in the UK, Euro Bus Rev 13(2): 86-95.

Williams, R. (2000). A note on robust variance estimation for cluster-correlated data, Biomet, 56: 645-646.

Yermack D (1996). Higher market evaluation of companies with small board of directors. J of Finan Econ 40: 185-212.

Zahra S A, Pearce JA (1989). Boards of directors and corporate financial performance: a review and integrative model. J of Manag 15: 291-301.

Zhang Y (2002). Voting rights, corporate control, and firm performance. Dissertation, Michigan State University, Michigan, USA.

Zahra S A, Stanton W W (1988). The implications of Board of Directors' composition on corporate strategy and performance. Intern J of Manag 5 (2): 229-236.

Zhu H, Wang P, Bart C (2016). Board processes, board strategic involvement, and organizational performance in for-profit and non-profit organizations. J of Bus Eth, 136 (2): 311-328. 
Table 1

Number of observations by country

\begin{tabular}{|c|c|c|c|}
\hline Country & Observations & Percentage & Cum. \\
\hline Australia & 678 & 6.6 & 6.6 \\
\hline Austria & 29 & 0.3 & 6.8 \\
\hline Belgium & 74 & 0.7 & 7.6 \\
\hline Brazil & 126 & 1.2 & 8.8 \\
\hline Canada & 1058 & 10.2 & 19.0 \\
\hline Chile & 47 & 0.5 & 19.5 \\
\hline China & 261 & 2.5 & 22.0 \\
\hline Denmark & 93 & 0.9 & 22.9 \\
\hline Egypt & 11 & 0.1 & 23.0 \\
\hline Finland & 124 & 1.2 & 24.2 \\
\hline France & 448 & 4.3 & 28.5 \\
\hline Germany & 83 & 0.8 & 29.3 \\
\hline Greece & 9 & 0.1 & 29.4 \\
\hline Hong Kong & 110 & 1.1 & 30.5 \\
\hline India & 125 & 1.2 & 31.7 \\
\hline Ireland & 159 & 1.5 & 33.2 \\
\hline Israel & 6 & 0.1 & 33.3 \\
\hline Italy & 98 & 1.0 & 34.3 \\
\hline Japan & 1011 & 9.8 & 44.1 \\
\hline Jersey & 18 & 0.2 & 44.3 \\
\hline Luxembourg & 56 & 0.5 & 44.8 \\
\hline Mexico & 84 & 0.8 & 45.6 \\
\hline Netherlands & 183 & 1.8 & 47.4 \\
\hline New Zealand & 51 & 0.5 & 47.9 \\
\hline Norway & 47 & 0.5 & 48.4 \\
\hline Portugal & 25 & 0.2 & 48.6 \\
\hline Russia & 121 & 1.2 & 49.8 \\
\hline South Africa & 61 & 0.6 & 50.4 \\
\hline Spain & 156 & 1.5 & 51.9 \\
\hline Sweden & 178 & 1.7 & 53.6 \\
\hline Switzerland & 227 & 2.2 & 55.8 \\
\hline Thailand & 69 & 0.7 & 56.5 \\
\hline United Kingdom & 1035 & 10.0 & 66.5 \\
\hline United States & 3453 & 33.5 & 100.0 \\
\hline Total & 10,314 & 100 & \\
\hline
\end{tabular}


Table 2

Corporate governance indicators

\begin{tabular}{|c|c|c|c|c|c|c|c|}
\hline Country & Legal origin & $\begin{array}{l}\text { Legal rights } \\
\text { strength's index }\end{array}$ & $\begin{array}{l}\text { Creditor rights' } \\
\text { index }\end{array}$ & $\begin{array}{c}\text { Legal protection } \\
\text { of minority } \\
\text { shareholders' } \\
\text { index }\end{array}$ & $\begin{array}{l}\text { Disclosure } \\
\text { requirements } \\
\text { index }\end{array}$ & $\begin{array}{l}\text { Shareholders' } \\
\text { rights-One } \\
\text { share/One vote }\end{array}$ & $\begin{array}{c}\text { Efficiency of judicial } \\
\text { system }\end{array}$ \\
\hline Australia & Common & High & Medium-high & High & High & 0 & High \\
\hline Austria & Civil & Medium-High & Medium-high & Low & Low & 0 & High \\
\hline Belgium & Civil & Medium-High & Low-medium & Medium-high & Low-medium & 0 & High \\
\hline Brazil & Civil & Low & Low & Low & Low & 1 & Medium-high \\
\hline Canada & Common & Medium-high & Low & Medium-high & High & 0 & High \\
\hline Chile & Civil & Low-medium & Low-medium & Medium-high & Medium-high & 1 & High \\
\hline China & Civil & Low-medium & Low-medium & High & Low-medium & 1 & n.a. \\
\hline Denmark & Civil & Medium-high & Medium-high & Low-medium & Medium-high & 0 & High \\
\hline Egypt & Civil & Low & Low-medium & Low-medium & Low-medium & 0 & Medium-high \\
\hline Finland & Civil & Medium-high & Low & Low-medium & Low-medium & 0 & High \\
\hline France & Civil & Medium-high & Low & Low-medium & High & 0 & High \\
\hline Germany & Civil & High & Medium-high & Low & Low-medium & 0 & High \\
\hline Greece & Civil & Low & Low & Low & Low-medium & 1 & Medium-high \\
\hline Hong Kong & Common & High & High & High & High & 1 & High \\
\hline India & Common & High & Low-medium & Medium-high & High & 0 & High \\
\hline Ireland & Common & High & Low & Medium-high & Medium-high & 0 & High \\
\hline Israel & Common & High & Medium-high & High & Medium-high & 0 & High \\
\hline Italy & Civil & Low & Low-medium & Low-medium & Medium-high & 0 & Medium-high \\
\hline Japan & Civil & Medium-high & Low-medium & Low-medium & High & 1 & High \\
\hline Jersey & Common & n.a. & n.a. & n.a. & n.a. & 0 & n.a. \\
\hline Luxembourg & Civil & Medium-high & n.a. & Low & n.a. & 1 & n.a. \\
\hline Mexico & Civil & Medium-high & Low & Low & Medium-high & 0 & Medium-high \\
\hline Netherlands & Civil & Medium-high & Medium-high & Low & Low-medium & 0 & High \\
\hline New Zealand & Common & High & High & High & Medium-high & 0 & High \\
\hline Norway & Civil & Medium-high & Low-medium & Low-medium & Medium-high & 0 & High \\
\hline Portugal & Civil & Low & Low & Low-medium & Low-medium & 0 & Medium-high \\
\hline Russia & Civil & Low & Low-medium & Low-medium & n.a. & 1 & n.a. \\
\hline South Africa & Common & High & Medium-high & High & High & 0 & Medium-high \\
\hline Spain & Civil & Medium-high & Low-medium & Low-medium & Low-medium & 0 & Medium-high \\
\hline Sweden & Civil & Low-medium & Low & Low-medium & Medium-high & 0 & High \\
\hline
\end{tabular}




\begin{tabular}{|c|c|c|c|c|c|c|c|}
\hline Switzerland & Civil & High & Low & Low & Medium-high & 0 & High \\
\hline Thailand & Common & Low-medium & Low-medium & High & High & 0 & Low-medium \\
\hline United Kingdom & Common & High & High & High & High & 0 & High \\
\hline United States & Common & High & Low & Medium-high & High & 0 & High \\
\hline \multicolumn{2}{|l|}{ Indicator } & \multicolumn{6}{|l|}{ Definition } \\
\hline \multicolumn{2}{|c|}{ Legal origin } & \multicolumn{6}{|c|}{ Common law country vs Civil law country } \\
\hline \multicolumn{2}{|c|}{ Legal rights strength's index } & \multicolumn{6}{|c|}{$\begin{array}{l}\text { Strength of legal rights index ranges between } 0 \text { and } 10 \\
(0-3=\text { Low, } 3-5=\text { Low-medium, 5-7= Medium-high, } 7-10=\text { High })\end{array}$} \\
\hline \multicolumn{2}{|c|}{ Creditor rights' index } & \multicolumn{6}{|c|}{$\begin{array}{l}\text { Creditor rights aggregate score ranges between } 0 \text { and } 4 \\
(0-1=\text { Low, } 1-2=\text { Low-medium, } 2-3=\text { Medium-high, } 3-4=\text { High })\end{array}$} \\
\hline \multicolumn{2}{|c|}{$\begin{array}{l}\text { Legal protection of minority } \\
\text { shareholders' index }\end{array}$} & \multicolumn{6}{|c|}{$\begin{array}{l}\text { Legal protection of minority shareholders' index ranges between } 0 \text { and } 100 \\
(0-30=\text { Low, } 30-50=\text { Low-medium, } 50-70=\text { Medium-high, } 70-100=\text { High })\end{array}$} \\
\hline \multicolumn{2}{|c|}{ Disclosure requirements' index } & \multicolumn{6}{|c|}{$\begin{array}{l}\text { Disclosure requirements' index ranges between } 0 \text { and } 100 \\
(0-30=\text { Low, } 30-50=\text { Low-medium, } 50-70=\text { Medium-high, } 70-100=\text { High })\end{array}$} \\
\hline \multicolumn{2}{|c|}{ Shareholders'rights-One share/One vote } & \multicolumn{6}{|c|}{ Dummy variable that takes the value 1 if this right exists in the law and 0 , otherwise } \\
\hline \multicolumn{2}{|c|}{ Efficiency of judicial system } & \multicolumn{6}{|c|}{$\begin{array}{l}\text { The degree to which the judicial system of a country can guarantee compliance with laws and recommendations ranging from } 0 \\
\text { to } 10 \\
\text { (0-3=Low, 3-5=Low-medium, } 5-7=\text { Medium-high, } 7-10=\text { High) }\end{array}$} \\
\hline
\end{tabular}


Table 3

Number of observations by activity sector

\begin{tabular}{lccc}
\hline \multicolumn{1}{c}{ TRBC economic sector name } & Number of observations & Percentage & Cum. \\
\hline Basic Materials & 1,367 & 13.25 & 13.2 \\
Consumer Cyclicals & 1,948 & 18.88 & 32.1 \\
Consumer Non-Cyclicals & 997 & 9.66 & 41.8 \\
Energy & 1,110 & 10.76 & 52.6 \\
Healthcare & 825 & 7.99 & 60.6 \\
Industrials & 2,135 & 20.70 & 81.3 \\
Technology & 885 & 8.58 & 89.9 \\
Telecommunications Services & 395 & 3.82 & 93.7 \\
Utilities & 652 & 6.32 & 100.0 \\
\hline Total & $\mathbf{1 0 , 3 1 4}$ & $\mathbf{1 0 0}$ & \\
\hline
\end{tabular}


Table 4

Variables description

\begin{tabular}{|c|c|}
\hline Variables & Description \\
\hline Q_TOBIN & $\begin{array}{l}\text { The market capitalization of common stock }+ \text { book value liabilities divided by the book } \\
\text { value of total assets }\end{array}$ \\
\hline B_SIZE & The total number of directors on boards \\
\hline B_INDEP & $\begin{array}{l}\text { Proportion of independent directors on boards }=\text { Total number of independent on boards } / \\
\text { Total number of directors on boards }\end{array}$ \\
\hline CEO_DUALITY & $\begin{array}{l}\text { Dummy variable that takes the value } 1 \text { if the same person serves simultaneously as CEO } \\
\text { and President of the board and } 0 \text {, otherwise }\end{array}$ \\
\hline FEM_DIR & $\begin{array}{l}\text { Proportion of female directors on boards= Total number of female directors on } \\
\text { boards/Total number of directors no boards }\end{array}$ \\
\hline B_COMPENSATION & Log of board compensation \\
\hline B_MEETING & Number of meetings held by boards every year \\
\hline SIZE & The log of total assets \\
\hline LEVERAGE & Debt over total assets \\
\hline CAPITAL_INTENSITY & Ratio of long-term or fixed assets over total assets \\
\hline OWNSHIP_CON & $\begin{array}{l}\text { Average percentage of shares held by the three largest shareholders in the ten largest } \\
\text { firms in each country }\end{array}$ \\
\hline DUAL_CLASS & $\begin{array}{l}\text { Dummy variable that takes the value } 1 \text { if firms have dual-class stocks (class } \mathrm{A} / \mathrm{B} \text { or } \\
\text { registered/bearer shares) and } 0 \text {, otherwise }\end{array}$ \\
\hline OPERATING_PERFORM & Operating performance is measured as the ratio between operating income and total assets \\
\hline BASIC MATERIALS & Dummy variable: $1=$ Basic Materials; $0=$ Otherwise \\
\hline CONSUMER CYCLICAL & Dummy variable: $1=$ Consumer Cyclical; $0=$ Otherwise \\
\hline $\begin{array}{l}\text { CONSUMER } \\
\text { CYCLICAL }\end{array}$ & Dummy variable: $1=$ Consumer Non-Cyclical; $0=$ Otherwise \\
\hline ENERGY & Dummy variable: $1=$ Energy; $0=$ Otherwise \\
\hline HEALTHCARE & Dummy variable: $1=$ Healthcare; $0=$ Otherwise \\
\hline INDUSTRIALS & Dummy variable: $1=$ Industrial; $0=$ Otherwise \\
\hline TECHNOLOGY & Dummy variable: $1=$ Technology; $0=$ Otherwise \\
\hline $\begin{array}{l}\text { TELECOMMUNICATION } \\
\text { SERVICES }\end{array}$ & Dummy variable: $1=$ Telecommunication Services; $0=$ Otherwise \\
\hline UTILITIES & Dummy variable: $1=$ Utilities; $0=$ Otherwise \\
\hline AFRICA & Dummy variable: $1=$ If the country is in Africa; $0=$ Otherwise \\
\hline ASIA & Dummy variable: $1=$ If the country is in Asia; $0=$ Otherwise \\
\hline EUROPE & Dummy variable: $1=$ If the country is in Europe; $0=$ Otherwise \\
\hline LATINAMERICA & Dummy variable: $1=$ If the country is in Latin America; $0=$ Otherwise \\
\hline NORTHAMERICA & Dummy variable: $1=$ If the country is in North America; $0=$ Otherwise \\
\hline OCEANIA & Dummy variable: $1=$ If the country is in Oceania; $0=$ Otherwise \\
\hline
\end{tabular}


Table 5

Descriptive analysis

\begin{tabular}{lccc}
\hline \multicolumn{1}{c}{ Variable } & Obs & Mean & $\begin{array}{c}\text { Standard } \\
\text { Deviation }\end{array}$ \\
\hline Q_TOBIN & 10314 & 0.57 & 0.20 \\
B_SIZE & 10314 & 10.60 & 3.20 \\
B_INDEP & 10314 & 63.60 & 26.04 \\
CEO_DUALITY & 10314 & 30.00 & 46.00 \\
FEM_DIR & 10314 & 11.90 & 10.73 \\
B_COMPENSATION & 10314 & 13.60 & 1.00 \\
B_MEETING & 10314 & 8.50 & 5.21 \\
SIZE & 10314 & 9.60 & 1.45 \\
LEVERAGE & 10314 & 13.00 & 24.09 \\
CAPITAL_INTENSITY & 10314 & 6.40 & 5.99 \\
OWNSHIP_CON & 10314 & 30.04 & 13.77 \\
DUAL_CLASS & 10314 & 13.15 & 33.79 \\
OPERATING_PERFORM & 10314 & 13.74 & 13.19 \\
BASIC MATERIALS & 10314 & 13.25 & 33.90 \\
CONSUMER CYCLICAL & 10314 & 18.88 & 39.14 \\
CONSUMER NON-CYCLICAL & 10314 & 9.66 & 29.55 \\
ENERGY & 10314 & 10.76 & 30.99 \\
HEALTHCARE & 10314 & 7.99 & 27.12 \\
INDUSTRIALS & 10314 & 20.70 & 40.51 \\
TECHNOLOGY & 10314 & 8.58 & 28.00 \\
TELECOMMUNICATION SERVICES & 10314 & 3.82 & 19.19 \\
UTILITIES & 10314 & 6.32 & 24.33 \\
AFRICA & 10314 & 0.70 & 8.33 \\
ASIA & 10314 & 15.31 & 36.00 \\
EUROPE & 10314 & 30.70 & 46.12 \\
LATINAMERICA & 10314 & 2.49 & 15.58 \\
NORTHAMERICA & 10314 & 43.74 & 49.61 \\
OCEANIA & 10314 & 7.07 & 25.63 \\
\hline & & & \\
\hline & & & \\
& & &
\end{tabular}

Mean and standard deviation. Q_TOBIN is the market capitalization of common stock+ book value liabilities divided by the book value of total assets; B_SIZE is the total number of directors on boards; B_INDEP is the proportion of independent directors on boards= Total number of independent on boards/ Total number of directors on boards; CEO_DUALITY is a dummy variable that takes the value 1 if the same person serves simultaneously as CEO and President of the board and 0, otherwise; FEM_DIR is the Proportion of female directors on boards= Total number of female directors on boards/Total number of directors no boards; B_COMPENSATION is the log of board compensation; B_MEETING is the number of meetings held by boards every year; SIZE is the log of total assets; LEVERAGE is debt over total assets; CAPITAL_INTENSITY is the ratio of long-term or fixed assets over total assets; OWNSHIP_CON is the average percentage of shares held by the three largest shareholders in the ten largest firms in each country; DUAL_CLASS is a dummy variable that takes the value 1 if firms have dual-class stocks (class A/B or registered/bearer shares) and 0, otherwise; OPERATING_PERFORM is the ratio between operating income and total assets; BASIC MATERIALS is a dummy variable: 1= Basic Materials; $0=$ Otherwise; CONSUMER CYCLICAL is a dummy variable: $1=$ Consumer Cyclical; $0=$ Otherwise; CONSUMER NON-CYCLICAL is a dummy variable: $1=$ Consumer Non-Cyclical; $0=$ Otherwise; HEALTHCARE is a dummy variable: $1=$ Healthcare; $0=$ Otherwise; INDUSTRIALS is a dummy variable: $1=$ Industrial; $0=$ Otherwise; TECHNOLOGY is a dummy variable: $1=$ Technology; $0=$ Otherwise; TELECOMMUNICATION SERVICES is a dummy variable: $1=$ Telecommunication Services; $0=$ Otherwise and UTILITIES is a dummy variable: $1=$ Utilities; $0=$ Otherwise. AFRICA is a dummy variable: $1=$ If the country is in Africa; $0=$ Otherwise; ASIA is a dummy variable: $1=$ If the country is in Asia; $0=$ Otherwise; EUROPE is a dummy variable: $1=$ If the country is in Europe; $0=$ Otherwise; LATINAMERICA is a dummy variable: $1=$ If the country is in Latin America; 0=Otherwise; NORTHAMERICA is a dummy variable: $1=$ If the country is in North America; $0=$ Otherwise; OCEANIA is a dummy variable: $1=$ If the country is in Oceania; $0=$ Otherwise. 
Table 6

Correlation matrix

\begin{tabular}{|c|c|c|c|c|c|c|c|c|c|c|c|c|c|c|c|c|c|c|}
\hline & & & & & & & & & & & & & & & & & & \\
\hline $\begin{array}{l}\text { Q_TOBIN (1) } \\
\text { B SIZE (2) }\end{array}$ & $\begin{array}{l}1000 \\
0.1788^{* * *} \\
0\end{array}$ & & & & & & & & & & & & & 114 & & (110) & (17it & \\
\hline $\begin{array}{l}\text { B__IIE (2) } \\
\text { B INDEP (3) }\end{array}$ & $\begin{array}{l}0.177 * * * \\
0.005 * * \\
0.06 * * * *\end{array}$ & $\begin{array}{ll}1.000 * * \\
-0.079 * * *\end{array}$ & 1.000 & & & & & & & & & & & & & & & \\
\hline $\begin{array}{l}\text { CEO_DUALITY (4) } \\
\text { FEM_DIR (5) }\end{array}$ & 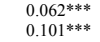 & $\begin{array}{l}0.122 * * * \\
0.131 * * *\end{array}$ & $\begin{array}{l}0.195 * * * \\
0.399 * * *\end{array}$ & $\begin{array}{l}1.000 \\
0.07 * * *\end{array}$ & & & & & & & & & & & & & & \\
\hline 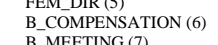 & $\begin{array}{l}0.10101 * * \\
0.08 \% * * * \\
0.05 \% * * *\end{array}$ & 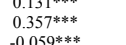 & $\begin{array}{l}0.392^{* * *} \\
0.060^{* * *}\end{array}$ & 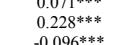 & $\begin{array}{l}1.000 * \\
0.270 * * * \\
0.068 * * *\end{array}$ & $\begin{array}{l}1.000 \\
-0.48 * * *\end{array}$ & & & & & & & & & & & & \\
\hline $\begin{array}{l}\text { B_MEETING (7) } \\
\text { SIZE (8) }\end{array}$ & $\begin{array}{l}0.253 * * * \\
0.27 * * *\end{array}$ & $\begin{array}{l}-0.059 * * * * \\
0.515^{* * * *}\end{array}$ & $\begin{array}{l}0.069^{* * * *} \\
0.04 *\end{array}$ & 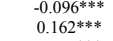 & $\begin{array}{l}0.063^{* * *} \\
0.123^{* * * *}\end{array}$ & $\begin{array}{l}-0.048^{* * *} \\
0.422^{* * * *}\end{array}$ & $\begin{array}{l}1.000 * \\
0.035 * *\end{array}$ & 1.000 & & & & & & & & & & \\
\hline $\begin{array}{l}\text { LEVERAGE (9) } \\
\text { CAPITAL_INTENSITY }\end{array}$ & $\begin{array}{l}0.765 * * * \\
-0.080^{* * * *}\end{array}$ & $\begin{array}{l}0.164 * * * \\
0.032 * * *\end{array}$ & $\begin{array}{l}-0.012 \\
-0.040^{* * *}\end{array}$ & $\begin{array}{l}0.030 * * * \\
-0.030^{* * *}\end{array}$ & $\begin{array}{l}0.055 * * * \\
-0.121 * * *\end{array}$ & $\begin{array}{l}0.0677^{* * * *} \\
-0.054^{* * * *}\end{array}$ & $\begin{array}{l}0.067 * * * \\
0.007\end{array}$ & $\begin{array}{l}0.270 * * * \\
0.021 * *\end{array}$ & $\begin{array}{l}1.000 \\
0.006\end{array}$ & 1.000 & & & & & & & & \\
\hline $\begin{array}{l}(10) \\
\text { OWNSHIP_CON (11) }\end{array}$ & $-0.0966^{* * *}$ & $0.019 * *$ & $0.046^{* * *}$ & $-0.133^{* * * *}$ & 0.012 & $-0.023^{* *}$ & 0.008 & $-0.068^{* * * *}$ & $-0.032^{* * * *}$ & $0.175^{* * * *}$ & & & & & & & & \\
\hline $\begin{array}{l}\text { DUAL_CLĀASS (12) } \\
\text { OPERATING_PERFORM }\end{array}$ & $\begin{array}{l}0.037 * * * \\
-0.214^{* * *}\end{array}$ & $\begin{array}{c}0.131 * * * \\
-0.015\end{array}$ & $\begin{array}{l}-0.101 * * * \\
0.142 * *\end{array}$ & $\begin{array}{l}-0.027^{*} \\
0.036^{* * * *}\end{array}$ & $\begin{array}{l}0.06 \% * * * \\
0.072^{* * * *}\end{array}$ & $\begin{array}{l}-0.043 * * * \\
0.137 * * *\end{array}$ & $\begin{array}{l}-0.042 * * \\
-0.066^{* * *}\end{array}$ & $\begin{array}{l}0.067 * * \\
-0.016^{*}\end{array}$ & $\begin{array}{l}0.029 * * * \\
-0.122^{* * *}\end{array}$ & $\begin{array}{l}-0.058 * * * \\
0.111 * * *\end{array}$ & $\begin{array}{l}0.110^{0 * * *} \\
0.122^{* * * * *}\end{array}$ & $\begin{array}{r}1.000 \\
-0.013\end{array}$ & 1.000 & & & & & \\
\hline $\begin{array}{l}\text { (13)IIC MATERIALS (14) } \\
\text { CONSUMER CYCLICAL }\end{array}$ & $\begin{array}{l}-0.128^{* * * *} \\
-0.012 \\
{ }^{2}\end{array}$ & $\begin{array}{l}-0.069^{* * *} \\
-0.027 * *\end{array}$ & $\begin{array}{l}-0.002 \\
-0.068^{* * *}\end{array}$ & $\begin{array}{l}-0.089 * * * \\
0.006\end{array}$ & $\begin{array}{l}-0.100 * * * * \\
0.077 * * * *\end{array}$ & $\begin{array}{l}-0.021 * * \\
-0.038^{* * * *}\end{array}$ & $\begin{array}{l}0.017^{*} \\
-0.077^{* * *}\end{array}$ & $\begin{array}{l}-0.062^{* * *} \\
-0.094^{* * *}\end{array}$ & $\begin{array}{l}-0.051 * * * \\
-0.033^{* * *}\end{array}$ & $\begin{array}{l}0.142 * * * \\
-0.095 * * *\end{array}$ & $\begin{array}{l}0.104 * * * \\
-0.112 * * *\end{array}$ & $\begin{array}{l}-0.039 * * * \\
0.100 * * *\end{array}$ & $\begin{array}{l}-0.063^{* * *} \\
-0.105^{* * *}\end{array}$ & $\begin{array}{l}1.000 \\
-0.188 * * *\end{array}$ & 1.000 & & & \\
\hline CONSUMER NON- & $0.072^{* * * *}$ & $0.089 * * *$ & $-0.032^{* * * *}$ & 0.003 & $0.122 * * *$ & $0.020^{*}$ & -0.015 & $0.031^{* *}$ & $0.066^{* * * *}$ & $-0.058^{* * * *}$ & -0.009 & $0.058 * * *$ & $-0.076^{* * * *}$ & $-0.127 * * *$ & $-0.158^{* * * *}$ & 1.000 & & \\
\hline $\begin{array}{l}\text { ENERGY (17) } \\
\text { ENELA }\end{array}$ & $-0.111 * * *$ & ${ }^{-0.007}$ & $0.073 * *$ & 0.013 & $-0.106^{* * * *}$ & $0.028 * * *$ & $0.022^{* * *}$ & $0.090 * * *$ & $-0.082^{* * * *}$ & $0.308^{* * * *}$ & $0.173^{* * *}$ & $-0.053 * * *$ & $0.096 * * *$ & $-0.135^{* * *}$ & $-0.168^{* * * *}$ & $-0.113^{* * *}$ & & \\
\hline $\begin{array}{l}\text { HEALTTCARE (18) } \\
\text { INDSTRIAL (19) }\end{array}$ & $\begin{array}{l}-0.132 * * \\
0.211 * * *\end{array}$ & 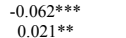 & $\begin{array}{l}0.088^{* * *} \\
-0.068^{* * * *}\end{array}$ & $\begin{array}{l}0.037 * * * \\
0.013\end{array}$ & 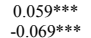 & $\begin{array}{l}0.089 * * * \\
-0.08 *^{* * * *}\end{array}$ & $\begin{array}{c}0.014 \\
-0.017^{*}\end{array}$ & $\begin{array}{c}-0.063 * 3 * \\
-0.007\end{array}$ & $\begin{array}{l}-0.086 * * * \\
0.1116^{* * * *}\end{array}$ & 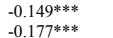 & - & $\begin{array}{l}-0.015 \\
-0.011\end{array}$ & $\begin{array}{l}0.106 * * * \\
-0.09 * * * * \\
0\end{array}$ & $\begin{array}{l}-0.115 * * * \\
-0.199 * * *\end{array}$ & $\begin{array}{l}-0.142 * * \\
-0.247^{* * * *}\end{array}$ & $\begin{array}{l}-0.096^{* * *} \\
-0.166^{* * * *}\end{array}$ & $\begin{array}{l}-0.150 * * * \\
-0.000 * * *\end{array}$ & $\begin{array}{l}1.000 \\
-0.150^{* * *}\end{array}$ \\
\hline TECHNOLOGY (20) & $-0.172^{* * * *}$ & $-0.076^{* * * *}$ & $0.049 * *$ & $0.017^{*}$ & $-0.022^{2 * * * *}$ & $0.051^{* * * *}$ & 0.001 & $\begin{array}{l}-0.063^{* * * *} \\
-0.4\end{array}$ & 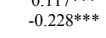 & $\begin{array}{l}-0.124 * * * \\
-0.0112\end{array}$ & & & $\begin{array}{l}0.069 * * * * \\
0.069\end{array}$ & 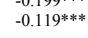 & $\begin{array}{l}-0.248^{* * * *} \\
-0.04\end{array}$ & $\begin{array}{l}-0.100 * * * \\
-0.0 .100\end{array}$ & $\begin{array}{l}-0.058 * * * \\
-0.058\end{array}$ & $-0.090^{* * *}$ \\
\hline TELECOMM SERVICES & $0.075^{* * * *}$ & $0.075^{* * * *}$ & $-0.027 * * * *$ & -0.015 & $0.025^{* *}$ & -0.010 & $0.076^{* * * *}$ & $0.099 * * *$ & $0.109 * * *$ & $0.165 * * *$ & $\begin{array}{l}0.073 * * * * * \\
0.078 * * *\end{array}$ & $0.022^{* *}$ & $0.091 * * *$ & $0.165^{* * *}$ & $-0.096^{* * * *}$ & $-0.069^{* * * *}$ & $-0.076^{* * *}$ & $-0.058^{* * * *}$ \\
\hline $\begin{array}{l}\text { (21) } \\
\text { UTILITIES (22) }\end{array}$ & $0.177^{* * * *}$ & $0.12^{* * * *}$ & $0.038^{* * *}$ & $0.022^{* * *}$ & $0.065^{* * * *}$ & $0.023^{* * *}$ & $0.043^{* * * *}$ & $0.160^{* * *}$ & $0.225 * * *$ & $0.107 * * *$ & $0.033^{* * * *}$ & $-0.05 \% * * *$ & $0.111^{* * * *}$ & $-0.101^{* * * *}$ & $-0.125^{* * *}$ & $-0.090^{* * * *}$ & $-0.076^{* * *}$ & $-0.076^{* * *}$ \\
\hline AFRICA (23) & $-0.018^{*}$ & $\begin{array}{l}0.043 * * * \\
0.090 * * * *\end{array}$ & $-0.045 * * * *$ & $\begin{array}{ll}-0.0588^{* * *} \\
0.0019 * *\end{array}$ & $\begin{array}{ll}0.038 * * * \\
-0.077 * * * *\end{array}$ & $\begin{array}{ll}-0.037 * * * \\
-0.474 * * *\end{array}$ & $\begin{array}{l}-0.055^{* * *} \\
-0.048 * *\end{array}$ & $\begin{array}{ll}-0.023 * * \\
0.013 * * *\end{array}$ & $\begin{array}{ll}-0.0233 * * \\
0.033 * * *\end{array}$ & $\begin{array}{ll}0.079 * * * \\
-0.015 * * *\end{array}$ & $\begin{array}{ll}0.019 * \\
-0.07 * * * *\end{array}$ & $\begin{array}{l}0.014 \\
-0.18 * * * *\end{array}$ & 0.0153 & $-0.019^{* * *}$ & $\begin{array}{l}0.012 \\
0.02 * * *\end{array}$ & $\begin{array}{l}0.013 \\
-0.039 * * *\end{array}$ & $-0.034 * * *$ & $\begin{array}{l}-0.034 * * * \\
0.080 * * * *\end{array}$ \\
\hline $\begin{array}{l}\text { EUROPE (25) } \\
\text { EURO }\end{array}$ & $\begin{array}{ll}-0.014 * * \\
0.13 * * *\end{array}$ & 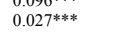 & $\begin{array}{l}-0.192 * * * \\
-0.028\end{array}$ & $\begin{array}{l}-0.029 * * * * \\
-0.029\end{array}$ & $0.049 * * *$ & $\begin{array}{l}-0.4 / 4 * * \\
-0.052 * * *\end{array}$ & $\begin{array}{l}-0.0648 * * * \\
0.064 * *\end{array}$ & $\begin{array}{l}0.032 * * * \\
0.113 *\end{array}$ & $\begin{array}{l}0.052 * * * * \\
0.053\end{array}$ & $\begin{array}{ll}0.142 * * * \\
0.027 *\end{array}$ & $0.174 * * *$ & $\begin{array}{l}-0.018911 \\
-0.011\end{array}$ & $\begin{array}{l}-0.0012 \\
0.012\end{array}$ & $\begin{array}{l}-0.023 \\
0.009\end{array}$ & $\begin{array}{l}-0.042 \\
0.002\end{array}$ & $\begin{array}{l}-0.0017^{*} \\
-0.039\end{array}$ & $0.068 * * *$ & $\begin{array}{l}0.086 * * * \\
0.06 \% *\end{array}$ \\
\hline LATINAMERICA (26) & $-0.019 *$ & 0.005 & $-0.139 * * *$ & $-0.042 * * *$ & $-0.093 * * *$ & $-0.168 * * *$ & $-0.186 * * *$ & 0.005 & $0.033^{* * * *}$ & $0.247^{* * * *}$ & $-0.019^{*}$ & $0.066^{* * * *}$ & $0.042^{* * * *}$ & $-0.032 * * *$ & $0.050^{* * * *}$ & $-0.033^{* * *}$ & -0.015 & -0.015 \\
\hline $\begin{array}{l}\text { NORTHAMERICA (27) } \\
\text { OCEANIA (28) }\end{array}$ & 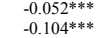 & $\begin{array}{l}0.043 * * * \\
-0.28 s^{* * * *}\end{array}$ & $\begin{array}{l}0.593^{* * *} \\
0.040^{* * *}\end{array}$ & $\begin{array}{l}0.341 * * * \\
-0.017 \sigma^{* * * *}\end{array}$ & $\begin{array}{l}0.240 * * * \\
0.024^{* * *}\end{array}$ & $\begin{array}{l}0.471 * * * \\
-0.03 *^{* * * *}\end{array}$ & $\begin{array}{l}0.0577 * * \\
0.199 * * *\end{array}$ & $\begin{array}{c}0.007 \\
-0.029^{* * *}\end{array}$ & $\begin{array}{l}-0.063^{* * *} \\
-0.031^{* * * *}\end{array}$ & $\begin{array}{l}-0.111^{* * * *} \\
0.0936^{* * *}\end{array}$ & 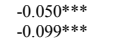 & $\begin{array}{l}0.120^{* * * *} \\
0.009\end{array}$ & 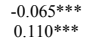 & $\begin{array}{l}-0.002 \\
0.046^{* * *}\end{array}$ & $\begin{array}{l}0.003 \\
-0.013\end{array}$ & $\frac{0.044 * *}{0.014}$ & $\begin{array}{l}-0.094 * * * \\
-0.035 * * *\end{array}$ & $\begin{array}{l}-0.094 * * \\
-0.035 * *\end{array}$ \\
\hline & & & & & & & & & & & & & & & & & & \\
\hline 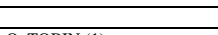 & (19) & $(20)$ & & (21) & $(22)$ & $(23)$ & & (24) & $(25)$ & (26) & (27) & & & & & & & \\
\hline & & & & & & & & & & & & & & & & & & \\
\hline $\begin{array}{l}\text { B_INDEP (3) } \\
\text { CEO DUALITY (4) }\end{array}$ & & & & & & & & & & & & & & & & & & \\
\hline $\begin{array}{l}\text { FEM_DIR (5) } \\
\text { B_COMPENSATION (6) }\end{array}$ & & & & & & & & & & & & & & & & & & \\
\hline 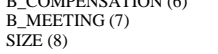 & & & & & & & & & & & & & & & & & & \\
\hline $\begin{array}{l}\text { LEVEAGE (9) } \\
\text { CAPITAL_INTENSITY }\end{array}$ & & & & & & & & & & & & & & & & & & \\
\hline $\begin{array}{l}\text { CAPITAL_INTENSITY } \\
\text { (10) } \\
\text { OWNSHIP CON (11) }\end{array}$ & & & & & & & & & & & & & & & & & & \\
\hline $\begin{array}{l}\text { OWNSHIP_CON (11) } \\
\text { DUAL_CASS (12) }\end{array}$ & & & & & & & & & & & & & & & & & & \\
\hline $\begin{array}{l}\text { OPERATING_PERFORM } \\
\text { (13) }\end{array}$ & & & & & & & & & & & & & & & & & & \\
\hline $\begin{array}{l}\text { BASIC MATERIALS (14) } \\
\text { CONSUMER CYCLICAL }\end{array}$ & & & & & & & & & & & & & & & & & & \\
\hline $\begin{array}{l}\text { (15) } \\
\text { CONSUMER NON- }\end{array}$ & & & & & & & & & & & & & & & & & & \\
\hline $\begin{array}{l}\text { CYCLICA (16) } \\
\text { ENERGY (17) }\end{array}$ & & & & & & & & & & & & & & & & & & \\
\hline $\begin{array}{l}\text { ENERTY (17) (18) } \\
\text { HEALTCARE (1) }\end{array}$ & & & & & & & & & & & & & & & & & & \\
\hline $\begin{array}{l}\text { INDUSTRIALS (19) } \\
\text { TECHOLOGY }\end{array}$ & $\begin{aligned} & 1.000 \\
-0.156^{* * * *} & \end{aligned}$ & & & & & & & & & & & & & & & & & \\
\hline $\begin{array}{l}\text { TECHNOLOGY (20) } \\
\text { TELECOMM SERVICES }\end{array}$ & $\begin{array}{l}-0.102 * * * \\
-0.00\end{array}$ & $-0.061 * * *$ & & .000 & & & & & & & & & & & & & & \\
\hline $\begin{array}{l}\text { (21) } \\
\text { UTLITIES (22) }\end{array}$ & $-0.132 * * *$ & & & $052 * * *$ & & & & & & & & & & & & & & \\
\hline AFRICA (23) & 0.003 & $0.074 * * *$ & & $021^{* * *}$ & $-0.021 * *$ & & & & & & & & & & & & & \\
\hline $\begin{array}{l}\text { ASIA (24) } \\
\text { EURPEE (25) }\end{array}$ & 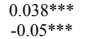 & $\begin{array}{l}-0.009 \\
0.05 *^{* * *}\end{array}$ & & $0.033^{* * *}$ & $\begin{aligned} & -0.009 \\
-0.033 * * & \end{aligned}$ & $\begin{array}{l}-0.032 * * * \\
-0.052 * *\end{array}$ & & $\begin{array}{l}1.000 \\
282^{* * *}\end{array}$ & & & & & & & & & & \\
\hline & $\begin{array}{l}-0.04 * * * * \\
-0.04 \% * *\end{array}$ & $\begin{array}{l}0.051 \% 3 \\
0.003\end{array}$ & & $3037 * * * * *$ & $\begin{array}{l}-0.037 * * * \\
0.037 * *\end{array}$ & - $\begin{array}{c}-0.022^{* * * *} \\
-0.05\end{array}$ & & 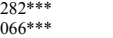 & $\begin{array}{l}1.000 * \\
-0.104 * * \\
\end{array}$ & & & & & & & & & \\
\hline $\begin{array}{l}\text { NORTAMAERICA (27) } \\
\text { OCEANIA (28) }\end{array}$ & $\begin{array}{l}0.077^{* * * *} \\
-0.077^{* * *}\end{array}$ & $\begin{array}{l}-0.049 * * * * \\
-0.009\end{array}$ & & $43^{4 * * * * * *}$ & $\begin{array}{l}0.047 * * * \\
-0.032 * * * \\
0\end{array}$ & $\begin{array}{l}-0.071 * * * \\
-0.018^{*}\end{array}$ & & $\begin{array}{l}374 * * * \\
116 * * *\end{array}$ & 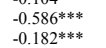 & $\begin{array}{l}-0.139 * * * \\
-0.041^{* * * *}\end{array}$ & $\begin{aligned} & 1.000 * \\
-0.242 * * * & \end{aligned}$ & & & & & & & \\
\hline
\end{tabular}


Q_TOBIN is the market capitalization of common stock+ book value liabilities divided by the book value of total assets; B_SIZE is the total number of directors on boards; B_INDEP is the proportion of independent directors on boards= Total number of independent on boards/ Total number of directors on boards; CEO_DUALITY is a dummy variable that takes the value 1 if the same person serves simultaneously as CEO and President of the board and 0, otherwise; FEM_DIR is the Proportion of female directors on boards= Total number of female directors on boards/Total number of directors no boards; B_COMPENSATION is the log of board compensation; B_MEETING is the number of meetings held by boards every year; SIZE is the log of total assets; LEVERAGE is debt over total assets; CAPITAL_INTENSITY is the ratio of long-term or fixed assets over total assets; OWNSHIP_CON is the average percentage of shares held by the three largest shareholders in the ten largest firms in each country; DUAL_CLASS is a dummy variable that takes the value 1 if firms have dual-class stocks (class A/B or registered/bearer shares) and 0, otherwise; OPERATING_PERFORM is the ratio between operating income and total assets; BASIC MATERIALS is a dummy variable: $1=$ Basic Materials; $0=$ Otherwise; CONSUMER CYCLICAL is a dummy variable: $1=$ Consumer Cyclical; $0=$ Otherwise; CONSUMER NON-CYCLICAL is a dummy variable: $1=$ Consumer Non-Cyclical; $0=$ Otherwise; HEALTHCARE is a dummy variable: $1=$ Healthcare; $0=$ Otherwise; INDUSTRIALS is a dummy variable: $1=$ Industrial; $0=$ Otherwise; TECHNOLOGY is a dummy variable: $1=$ Technology; $0=$ Otherwise; TELECOMMUNICATION SERVICES is a dummy variable: $1=$ Telecommunication Services; $0=$ Otherwise and UTILITIES is a dummy variable: $1=$ Utilities; $0=$ Otherwise. AFRICA is a dummy variable: $1=$ If the country is in Africa; $0=$ Otherwise; ASIA is a dummy variable: $1=$ If the country is in Asia; $0=0$ therwise; EUROPE is a dummy variable: $1=$ If the country is in Europe; $0=$ Otherwise; LATINAMERICA is a dummy variable: $1=$ If the country is in Latin America; $0=$ Otherwise; NORTHAMERICA is a dummy variable: $1=$ If the country is in North America; $0=$ Otherwise; OCEANIA is a dummy variable: $1=$ If the country is in Oceania; $0=$ Otherwise. $*$ p-value $<0.1 * *$ p-value $<0.05 * * *$ p-value $<0.01$. 
Table 7

Multivariate analysis results with Q_Tobin as dependent variable

\begin{tabular}{|c|c|c|c|c|c|c|}
\hline & $\begin{array}{c}\text { Model } 1 \\
\text { Coef. } \\
\mathbf{P}>|\mathbf{t}|\end{array}$ & $\begin{array}{c}\text { Model } 2 \\
\text { Coef. } \\
\mathbf{P}>|\mathbf{t}|\end{array}$ & $\begin{array}{c}\text { Model } 3 \\
\text { Coef. } \\
\mathbf{P}>|\mathbf{t}|\end{array}$ & $\begin{array}{c}\text { Model } 4 \\
\text { Coef. } \\
P>|\mathbf{t}|\end{array}$ & $\begin{array}{c}\text { Model } 5 \\
\text { Coef. } \\
\mathbf{P}>|\mathbf{t}|\end{array}$ & $\begin{array}{c}\text { Model } 6 \\
\text { Coef. } \\
\mathbf{P}>|\mathbf{t}|\end{array}$ \\
\hline B_SIZE & $\begin{array}{c}0.005^{* * *} * \\
(0.000)\end{array}$ & & & & & $\begin{array}{c}0.004 * * * \\
(0.000)\end{array}$ \\
\hline B_INDEP & & $\begin{array}{c}0.000 * * * \\
(0.001)\end{array}$ & & & & $\begin{array}{c}0.000 * * * \\
(0.000)\end{array}$ \\
\hline CEO_DUALITY & & & $\begin{array}{c}0.026 * * * \\
(0.000)\end{array}$ & & & $\begin{array}{c}0.023 * * * \\
(0.000)\end{array}$ \\
\hline FEM_DIR & & & & $\begin{array}{c}0.001 * * * \\
(0.000)\end{array}$ & & $\begin{array}{c}0.001 * * * \\
(0.000)\end{array}$ \\
\hline B_COMPENSATION & & & & & $\begin{array}{c}0.000 \\
(0.689)\end{array}$ & $\begin{array}{l}-0.001 \\
(0.125)\end{array}$ \\
\hline B_MEETING & $\begin{array}{c}0.001 * * * \\
(0.008)\end{array}$ & $\begin{array}{c}0.001 * * \\
(0.016)\end{array}$ & $\begin{array}{c}0.001 * * * \\
(0.006)\end{array}$ & $\begin{array}{c}0.001 * * \\
(0.017)\end{array}$ & $\begin{array}{c}0.001^{* *} \\
(0.012)\end{array}$ & $\begin{array}{c}0.001 * * * \\
(0.006)\end{array}$ \\
\hline SIZE & $\begin{array}{c}0.008 * * * \\
(0.000)\end{array}$ & $\begin{array}{c}0.010^{* * * *} * \\
(0.000)\end{array}$ & $\begin{array}{c}0.010^{* * * *} \\
(0.000)\end{array}$ & $\begin{array}{c}0.010^{* * * *} \\
(0.000)\end{array}$ & $\begin{array}{c}0.010^{* * * *} \\
(0.000)\end{array}$ & $\begin{array}{c}0.001^{* * * *} \\
(0.000)\end{array}$ \\
\hline LEVERAGE & $\begin{array}{c}0.000 \\
(0.150)\end{array}$ & $\begin{array}{c}0.000 \\
(0.131)\end{array}$ & $\begin{array}{c}0.000 \\
(0.146)\end{array}$ & $\begin{array}{c}0.000 \\
(0.140)\end{array}$ & $\begin{array}{c}0.000 \\
(0.135)\end{array}$ & $\begin{array}{c}0.000 \\
(0.159)\end{array}$ \\
\hline CAPITAL_INTENSITY & $\begin{array}{c}-0.002 * * * \\
(0.000)\end{array}$ & $\begin{array}{c}-0.002 * * * \\
(0.000)\end{array}$ & $\begin{array}{c}-0.003 * * * \\
(0.000)\end{array}$ & $\begin{array}{c}-0.002 * * * \\
(0.000)\end{array}$ & $\begin{array}{c}-0.003^{* * *} \\
(0.000)\end{array}$ & $\begin{array}{c}-0.002 * * * \\
(0.000)\end{array}$ \\
\hline OWNSHIP_CON & $\begin{array}{c}-0.001 * * * \\
(0.000)\end{array}$ & $\begin{array}{c}-0.001 * * * \\
(0.000)\end{array}$ & $\begin{array}{c}-0.001 * * * \\
(0.000)\end{array}$ & $\begin{array}{c}-0.001 * * * \\
(0.000)\end{array}$ & $\begin{array}{c}-0.001 * * * \\
(0.000)\end{array}$ & $\begin{array}{c}-0.001 * * * * \\
(0.000)\end{array}$ \\
\hline DUAL_CLASS & $\begin{array}{l}-0.000 \\
(0.977)\end{array}$ & $\begin{array}{c}0.005 \\
(0.312)\end{array}$ & $\begin{array}{c}0.004 \\
(0.462)\end{array}$ & $\begin{array}{c}0.002 \\
(0.695)\end{array}$ & $\begin{array}{c}0.004 \\
(0.505)\end{array}$ & $\begin{array}{c}0.001 \\
(0.823)\end{array}$ \\
\hline OPERATING_PERFORM & $\begin{array}{c}-0.002 * * * \\
(0.000)\end{array}$ & $\begin{array}{c}-0.002 * * * \\
(0.000)\end{array}$ & $\begin{array}{c}-0.002 * * * * \\
(0.000)\end{array}$ & $\begin{array}{c}-0.002 * * * \\
(0.000)\end{array}$ & $\begin{array}{c}-0.002^{* * *} * \\
(0.000)\end{array}$ & $\begin{array}{c}-0.002^{* * * *} \\
(0.000)\end{array}$ \\
\hline BASIC MATERIALS & $\begin{array}{c}-0.175 * * * \\
(0.000)\end{array}$ & $\begin{array}{c}-0.182 * * * \\
(0.000)\end{array}$ & $\begin{array}{c}-0.180 * * * * \\
(0.000)\end{array}$ & $\begin{array}{c}-0.177 * * * * \\
(0.000)\end{array}$ & $\begin{array}{c}-0.182 * * * * \\
(0.000)\end{array}$ & $\begin{array}{c}-0.172 * * * * \\
(0.000)\end{array}$ \\
\hline CONSUMER CYCLICAL & $\begin{array}{c}-0.129 * * * \\
(0.000)\end{array}$ & $\begin{array}{c}-0.133 * * * * \\
(0.000)\end{array}$ & $\begin{array}{c}-0.134 * * * \\
(0.000)\end{array}$ & $\begin{array}{c}-0.133^{* * * *} \\
(0.000)\end{array}$ & $\begin{array}{c}-0.134 * * * \\
(0.000)\end{array}$ & $\begin{array}{c}-0.127 * * * \\
(0.000)\end{array}$ \\
\hline CONSUMER NON-CYCLICAL & $\begin{array}{c}-0.088 * * * * \\
(0.000)\end{array}$ & $\begin{array}{c}-0.089 * * * \\
(0.000)\end{array}$ & $\begin{array}{c}-0.089 * * * \\
(0.000)\end{array}$ & $\begin{array}{c}-0.091 * * * \\
(0.000)\end{array}$ & $\begin{array}{c}-0.090 * * * \\
(0.000)\end{array}$ & $\begin{array}{c}-0.087 * * * * \\
(0.000)\end{array}$ \\
\hline ENERGY & $\begin{array}{c}-0.140 * * * \\
(0.000)\end{array}$ & $\begin{array}{c}-0.146 * * * \\
(0.000)\end{array}$ & $\begin{array}{c}-0.146 * * * \\
(0.000)\end{array}$ & $\begin{array}{c}-0.141 * * * \\
(0.000)\end{array}$ & $\begin{array}{c}-0.146 * * * \\
(0.000)\end{array}$ & $\begin{array}{c}-0.138 * * * * \\
(0.000)\end{array}$ \\
\hline HEALTHCARE & $\begin{array}{c}-0.199 * * * \\
(0.000)\end{array}$ & $\begin{array}{c}-0.207 * * * \\
(0.000)\end{array}$ & $\begin{array}{c}-0.207 * * * \\
(0.000)\end{array}$ & $\begin{array}{c}-0.204 * * * * \\
(0.000)\end{array}$ & $\begin{array}{c}-0.206^{* * * *} \\
(0.000)\end{array}$ & $\begin{array}{c}-0.199 * * * \\
(0.000)\end{array}$ \\
\hline INDUSTRIALS & $\begin{array}{c}-0.051 * * * \\
(0.000)\end{array}$ & $\begin{array}{c}-0.055^{* * * *} \\
(0.000)\end{array}$ & $\begin{array}{c}-0.056^{* * *} \\
(0.000)\end{array}$ & $\begin{array}{c}-0.052 * * * \\
(0.000)\end{array}$ & $\begin{array}{c}-0.055^{* * *} * \\
(0.000)\end{array}$ & $\begin{array}{c}-0.049^{* * * *} \\
(0.000)\end{array}$ \\
\hline TECHNOLOGY & $\begin{array}{c}-0.225 * * * \\
(0.000)\end{array}$ & $\begin{array}{c}-0.235 * * * \\
(0.000)\end{array}$ & $\begin{array}{c}-0.233 * * * \\
(0.000)\end{array}$ & $\begin{array}{c}-0.230 * * * \\
(0.000)\end{array}$ & $\begin{array}{c}-0.234 * * * \\
(0.000)\end{array}$ & $\begin{array}{c}-0.222 * * * * \\
(0.000)\end{array}$ \\
\hline TELECOMMUNICATION SERVICES & $\begin{array}{c}-0.039 * * * * \\
(0.000)\end{array}$ & $\begin{array}{c}-0.037 * * * * \\
(0.001)\end{array}$ & $\begin{array}{c}-0.039 * * * \\
(0.001)\end{array}$ & $\begin{array}{c}-0.038^{* * * *} \\
(0.001)\end{array}$ & $\begin{array}{c}-0.038^{* * * *} \\
(0.001)\end{array}$ & $\begin{array}{c}-0.038 * * * * \\
(0.001)\end{array}$ \\
\hline AFRICA & $\begin{array}{c}0.014 \\
(0.530)\end{array}$ & $\begin{array}{c}0.030 \\
(0.188)\end{array}$ & $\begin{array}{c}0.029 \\
(0.187)\end{array}$ & $\begin{array}{c}0.016 \\
(0.485)\end{array}$ & $\begin{array}{c}0.018 \\
(0.401)\end{array}$ & $\begin{array}{c}0.032 \\
(0.159)\end{array}$ \\
\hline
\end{tabular}




\begin{tabular}{|c|c|c|c|c|c|c|}
\hline ASIA & $\begin{array}{c}-0.017 * * * * \\
(0.002)\end{array}$ & $\begin{array}{c}0.009 \\
(0.278)\end{array}$ & $\begin{array}{l}-0.008 \\
(0.171)\end{array}$ & $\begin{array}{l}-0.001 \\
(0.885)\end{array}$ & $\begin{array}{l}-0.011^{*} \\
(0.085)\end{array}$ & $\begin{array}{c}0.013 \\
(0.143)\end{array}$ \\
\hline EUROPE & $\begin{array}{c}0.043 * * * \\
(0.000)\end{array}$ & $\begin{array}{c}0.051 * * * \\
(0.000)\end{array}$ & $\begin{array}{c}0.051 * * * \\
(0.000)\end{array}$ & $\begin{array}{c}0.044 * * * * \\
(0.000)\end{array}$ & $\begin{array}{c}0.043 * * * \\
(0.000)\end{array}$ & $\begin{array}{c}0.059 * * * \\
(0.000)\end{array}$ \\
\hline LATINAMERICA & $\begin{array}{c}0.031 * * * \\
(0.007)\end{array}$ & $\begin{array}{c}0.047^{* * *} * \\
(0.000)\end{array}$ & $\begin{array}{c}0.036^{* * * *} \\
(0.001)\end{array}$ & $\begin{array}{c}0.038^{* * * *} \\
(0.001)\end{array}$ & $\begin{array}{c}0.032 * * * \\
(0.009)\end{array}$ & $\begin{array}{c}0.051^{* * *} * \\
(0.000)\end{array}$ \\
\hline OCEANIA & $\begin{array}{c}-0.032 * * * \\
(0.000)\end{array}$ & $\begin{array}{c}-0.041 * * * \\
(0.000)\end{array}$ & $\begin{array}{c}-0.034 * * * \\
(0.000)\end{array}$ & $\begin{array}{c}-0.043 * * * \\
(0.000)\end{array}$ & $\begin{array}{c}-0.044 * * * \\
(0.000)\end{array}$ & $\begin{array}{c}-0.018 * * \\
(0.035)\end{array}$ \\
\hline Year effects & Yes & Yes & Yes & Yes & Yes & Yes \\
\hline $\mathrm{N}$ & 10,314 & 10,314 & 10,314 & 10,314 & 10,314 & 10,314 \\
\hline $\mathrm{R}^{2}$ & $19.34 \%$ & $18.93 \%$ & $19.13 \%$ & $19.06 \%$ & $18.81 \%$ & $19.89 \%$ \\
\hline F test & $86.21 * * *$ & $83.12 * * *$ & $85.81 * * *$ & $83.51 * * *$ & $82.96 * * *$ & $78.85^{* * *}$ \\
\hline
\end{tabular}

Q_TOBIN is the market capitalization of common stock+ book value liabilities divided by the book value of total assets; B_SIZE is the total number of directors on boards; B_INDEP is the proportion of independent directors on boards= Total number of independent on boards/ Total number of directors on boards; CEO DUALITY is a dummy variable that takes the value 1 if the same person serves simultaneously as CEO and President of the board and 0, otherwise; FEM_DIR is the Proportion of female directors on boards= Total number of female directors on boards/Total number of directors no boards; B_COMPENSATION is the log of board compensation; B_MEETING is the number of meetings held by boards every year; SIZE is the log of total assets; LEVERAGE is debt over total assets; CAPITAL_INTENSITY is the ratio of long-term or fixed assets over total assets; OWNSHIP CON is the average percentage of shares held by the three largest shareholders in the ten largest firms in each country; DUAL_CLASS is a dummy variable that takes the value 1 if firms have dual-class stocks (class A/B or registered/bearer shares) and 0 , otherwise; OPERATING_PERFORM is the ratio between operating income and total assets; BASIC MATERIALS is a dummy variable: $1=$ Basic Me Otherwise, HEALTHCARE is a don Otherwise, TELECOMMUNICATION SERVICES is a dummy variable. $1=$ Telecommunication Services, $0=$ Otherwise and UTLLITES is a dummy variable. $1=$ Utilities, $0=$ Otherwise. AFRICA is a dummy variable: $1=$ If the country is in Africa; $0=$ Otherwise; ASIA is a dummy variable: $1=$ If the country is in Asia; $0=$ Otherwise; EUROPE is a dummy variable: $1=$ If the country is in Europe; $0=$ Otherwise, LATINAMERICA is a dummy variable: $1=$ If the country is in Latin America; $0=$ Otherwise; NORTHAMERICA is a dummy variable: $1=$ If the country is in North America; $0=$ Otherwise; OCEANIA is a dummy variable: $1=$ If the country is in Oceania; $0=$ Otherwise. $*$ p-value $<0.1 * *$ p-value $<0.05 * * *$ p-value $<0.01$. 
Table 8

Regressions with lagged independent variables

\begin{tabular}{|c|c|c|c|c|c|c|}
\hline & $\begin{array}{c}\text { Model } 1 \\
\text { Coef. } \\
P>|t|\end{array}$ & $\begin{array}{c}\text { Model } 2 \\
\text { Coef. } \\
P>|t|\end{array}$ & $\begin{array}{c}\text { Model } 3 \\
\text { Coef. } \\
P>|t|\end{array}$ & $\begin{array}{l}\text { Model } 4 \\
\text { Coef. } \\
P>|t|\end{array}$ & $\begin{array}{l}\text { Model } 5 \\
\text { Coef. } \\
P>|t|\end{array}$ & $\begin{array}{c}\text { Model } 6 \\
\text { Coef. } \\
P>|t|\end{array}$ \\
\hline B_SIZE_1 & $\begin{array}{c}0.004 * * * \\
(0.000)\end{array}$ & & & & & $\begin{array}{c}0.005^{* * *} * \\
(0.000)\end{array}$ \\
\hline B_INDEP_1 & & $\begin{array}{c}0.000^{* * * *} \\
(0.000)\end{array}$ & & & & $\begin{array}{c}0.000^{* * * *} \\
(0.001)\end{array}$ \\
\hline CEO_DUALITY_1 & & & $\begin{array}{c}0.031 * * * \\
(0.000)\end{array}$ & & & $\begin{array}{c}0.027 * * * \\
(0.000)\end{array}$ \\
\hline FEM_DIR_1 & & & & $\begin{array}{c}0.001 * * * \\
(0.000)\end{array}$ & & $\begin{array}{c}0.001 * * * \\
(0.000)\end{array}$ \\
\hline B_COMPENSATION_1 & & & & & $\begin{array}{c}0.000 \\
(0.896)\end{array}$ & $\begin{array}{c}-0.001^{*} \\
(0.069)\end{array}$ \\
\hline B_MEETING & $\begin{array}{c}0.001 * * * \\
(0.007)\end{array}$ & $\begin{array}{c}0.001 \text { ** } \\
(0.010)\end{array}$ & $\begin{array}{c}0.001 * * * \\
(0.003)\end{array}$ & $\begin{array}{c}0.001^{* *} \\
(0.014)\end{array}$ & $\begin{array}{c}0.001 * * * \\
(0.008)\end{array}$ & $\begin{array}{c}0.001 * * * \\
(0.005)\end{array}$ \\
\hline SIZE & $\begin{array}{c}0.009 * * * \\
(0.000)\end{array}$ & $\begin{array}{c}0.011 * * * \\
(0.000)\end{array}$ & $\begin{array}{c}0.011 * * * \\
(0.000)\end{array}$ & $\begin{array}{c}0.011 * * * \\
(0.000)\end{array}$ & $\begin{array}{c}0.011 * * * \\
(0.000)\end{array}$ & $\begin{array}{c}0.008 * * * \\
(0.000)\end{array}$ \\
\hline LEVERAGE & $\begin{array}{c}0.000 * * * \\
(0.004)\end{array}$ & $\begin{array}{c}0.000 * * * \\
(0.005)\end{array}$ & $\begin{array}{c}0.000 * * * \\
(0.004)\end{array}$ & $\begin{array}{c}0.000 * * * \\
(0.004)\end{array}$ & $\begin{array}{c}0.000 * * * \\
(0.005)\end{array}$ & $\begin{array}{c}0.000 * * * \\
(0.004)\end{array}$ \\
\hline CAPITAL_INTENSITY & $\begin{array}{c}-0.003^{* * *} * \\
(0.000)\end{array}$ & $\begin{array}{c}-0.003^{* * *} * \\
(0.000)\end{array}$ & $\begin{array}{c}-0.003^{* * *} \\
(0.000)\end{array}$ & $\begin{array}{c}-0.002 * * * \\
(0.000)\end{array}$ & $\begin{array}{c}-0.003^{* * *} \\
(0.000)\end{array}$ & $\begin{array}{c}-0.002 * * * \\
(0.000)\end{array}$ \\
\hline OWNSHIP_CON & $\begin{array}{c}-0.001 * * * \\
(0.000)\end{array}$ & $\begin{array}{c}-0.001 * * * \\
(0.000)\end{array}$ & $\begin{array}{c}-0.001 * * * \\
(0.000)\end{array}$ & $\begin{array}{c}-0.001 * * * \\
(0.000)\end{array}$ & $\begin{array}{c}-0.001 * * * \\
(0.000)\end{array}$ & $\begin{array}{c}-0.001 * * * \\
(0.000)\end{array}$ \\
\hline DUAL_CLASS & $\begin{array}{l}-0.001 \\
(0.921)\end{array}$ & $\begin{array}{c}0.005 \\
(0.337)\end{array}$ & $\begin{array}{c}0.003 \\
(0.537)\end{array}$ & $\begin{array}{c}0.002 \\
(0.727)\end{array}$ & $\begin{array}{c}0.003 \\
(0.546)\end{array}$ & $\begin{array}{c}0.001 \\
(0.929)\end{array}$ \\
\hline OPERATING_PERFORM & $\begin{array}{c}-0.001 * * * \\
(0.000)\end{array}$ & $\begin{array}{c}-0.002 * * * \\
(0.000)\end{array}$ & $\begin{array}{c}-0.002 * * * * \\
(0.000)\end{array}$ & $\begin{array}{c}-0.002^{* * *} \\
(0.000)\end{array}$ & $\begin{array}{c}-0.002 * * * * \\
(0.000)\end{array}$ & $\begin{array}{c}-0.002^{* * * *} \\
(0.000)\end{array}$ \\
\hline BASIC MATERIALS & $\begin{array}{c}-0.174 * * * \\
(0.000)\end{array}$ & $\begin{array}{c}-0.181 * * * \\
(0.000)\end{array}$ & $\begin{array}{c}-0.178 * * * \\
(0.000)\end{array}$ & $\begin{array}{c}-0.174 * * * \\
(0.000)\end{array}$ & $\begin{array}{c}-0.181^{* * *} * \\
(0.000)\end{array}$ & $\begin{array}{c}-0.170 * * * \\
(0.000)\end{array}$ \\
\hline CONSUMER CYCLICAL & $\begin{array}{c}-0.126 * * * \\
(0.000)\end{array}$ & $\begin{array}{c}-0.129 * * * \\
(0.000)\end{array}$ & $\begin{array}{c}-0.131 * * * \\
(0.000)\end{array}$ & $\begin{array}{c}-0.130^{* * *} \\
(0.000)\end{array}$ & $\begin{array}{c}-0.131^{* * *} \\
(0.000)\end{array}$ & $\begin{array}{c}-0.1247 * * * \\
(0.000)\end{array}$ \\
\hline CONSUMER NON-CYCLICAL & $\begin{array}{c}-0.086 * * * * \\
(0.000)\end{array}$ & $\begin{array}{c}-0.087 * * * * \\
(0.000)\end{array}$ & $\begin{array}{c}-0.087 * * * \\
(0.000)\end{array}$ & $\begin{array}{c}-0.090 * * * \\
(0.000)\end{array}$ & $\begin{array}{c}-0.088 * * * \\
(0.000)\end{array}$ & $\begin{array}{c}-0.086 * * * \\
(0.000)\end{array}$ \\
\hline ENERGY & $\begin{array}{c}-0.142 * * * \\
(0.000)\end{array}$ & $\begin{array}{c}-0.148^{* * *} \\
(0.000)\end{array}$ & $\begin{array}{c}-0.147 * * * \\
(0.000)\end{array}$ & $\begin{array}{c}-0.141 * * * \\
(0.000)\end{array}$ & $\begin{array}{c}-0.147 * * * \\
(0.000)\end{array}$ & $\begin{array}{c}-0.138^{* * * *} \\
(0.000)\end{array}$ \\
\hline HEALTHCARE & $\begin{array}{c}-0.193 * * * * \\
(0.000)\end{array}$ & $\begin{array}{c}-0.202 * * * * \\
(0.000)\end{array}$ & $\begin{array}{c}-0.201^{* * * *} \\
(0.000)\end{array}$ & $\begin{array}{c}-0.198^{* * * *} \\
(0.000)\end{array}$ & $\begin{array}{c}-0.200^{* * * *} \\
(0.000)\end{array}$ & $\begin{array}{c}-0.1949 * * * \\
(0.000)\end{array}$ \\
\hline INDUSTRIALS & $\begin{array}{c}-0.050 * * * \\
(0.000)\end{array}$ & $\begin{array}{c}-0.054 * * * \\
(0.000)\end{array}$ & $\begin{array}{c}-0.055^{*} * * \\
(0.000)\end{array}$ & $\begin{array}{c}-0.050 * * * \\
(0.000)\end{array}$ & $\begin{array}{c}-0.054 * * * \\
(0.000)\end{array}$ & $\begin{array}{c}-0.047 * * * \\
(0.000)\end{array}$ \\
\hline TECHNOLOGY & $\begin{array}{c}-0.222 * * * \\
(0.000)\end{array}$ & $\begin{array}{c}-0.232 * * * * \\
(0.000)\end{array}$ & $\begin{array}{c}-0.229 * * * \\
(0.000)\end{array}$ & $\begin{array}{c}-0.225 * * * \\
(0.000)\end{array}$ & $\begin{array}{c}-0.231 * * * * \\
(0.000)\end{array}$ & $\begin{array}{c}-0.218 * * * \\
(0.000)\end{array}$ \\
\hline TELECOMMUNICATION SERVICES & $\begin{array}{c}-0.031^{* *} \\
(0.011)\end{array}$ & $\begin{array}{c}-0.030^{* *} \\
(0.015)\end{array}$ & $\begin{array}{c}-0.031^{* *} \\
(0.012)\end{array}$ & $\begin{array}{c}-0.030^{* *} \\
(0.013)\end{array}$ & $\begin{array}{c}-0.030^{* *} \\
(0.013)\end{array}$ & $\begin{array}{c}-0.031^{* *} \\
(0.011)\end{array}$ \\
\hline AFRICA & 0.018 & 0.034 & 0.036 & 0.018 & 0.023 & 0.036 \\
\hline
\end{tabular}




\begin{tabular}{|c|c|c|c|c|c|c|}
\hline \multirow[b]{2}{*}{ ASIA } & $(0.450)$ & $(0.141)$ & $(0.116)$ & $(0.440)$ & $(0.321)$ & $(0.135)$ \\
\hline & $\begin{array}{c}-0.020 * * * \\
(0.001)\end{array}$ & $\begin{array}{c}0.007 \\
(0.468)\end{array}$ & $\begin{array}{c}-0.010^{*} \\
(0.097)\end{array}$ & $\begin{array}{l}-0.002 \\
(0.728)\end{array}$ & $\begin{array}{c}-0.015^{* *} \\
(0.025)\end{array}$ & $\begin{array}{c}0.012 \\
(0.224)\end{array}$ \\
\hline EUROPE & $\begin{array}{c}0.038^{* * * *} \\
(0.000)\end{array}$ & $\begin{array}{c}0.046 * * * * \\
(0.000)\end{array}$ & $\begin{array}{c}0.0481 * * * * \\
(0.000)\end{array}$ & $\begin{array}{c}0.039 * * * \\
(0.000)\end{array}$ & $\begin{array}{c}0.038 * * * * \\
(0.000)\end{array}$ & $\begin{array}{c}0.057 * * * \\
(0.000)\end{array}$ \\
\hline LATINAMERICA & $\begin{array}{l}0.024^{*} \\
(0.067)\end{array}$ & $\begin{array}{c}0.042 * * * \\
(0.003)\end{array}$ & $\begin{array}{c}0.032 * * \\
(0.013)\end{array}$ & $\begin{array}{c}0.034 * * * \\
(0.009)\end{array}$ & $\begin{array}{l}0.025^{*} \\
(0.064)\end{array}$ & $\begin{array}{c}0.045 * * * \\
(0.002)\end{array}$ \\
\hline OCEANIA & $\begin{array}{c}-0.043 * * * \\
(0.000)\end{array}$ & $\begin{array}{c}-0.042 * * * \\
(0.000)\end{array}$ & $\begin{array}{c}-0.041^{* * *} * \\
(0.000)\end{array}$ & $\begin{array}{c}-0.054 * * * * \\
(0.000)\end{array}$ & $\begin{array}{c}-0.056^{* * * *} \\
(0.000)\end{array}$ & $\begin{array}{c}-0.026^{* *} * \\
(0.003) \\
\end{array}$ \\
\hline Year effects & Yes & Yes & Yes & Yes & Yes & Yes \\
\hline $\mathrm{N}$ & 8479 & 8479 & 8479 & 8479 & 8479 & 8479 \\
\hline $\mathrm{R}^{2}$ & $21.64 \%$ & $21.21 \%$ & $21.54 \%$ & $21.45 \%$ & $21.09 \%$ & $22.41 \%$ \\
\hline F test & $78.41 * * *$ & $75.64 * * *$ & $78.33 * * *$ & $76.35 * * *$ & $75.43 * * *$ & 71.76 *** \\
\hline
\end{tabular}

Q_TOBIN is the market capitalization of common stock+ book value liabilities divided by the book value of total assets; B_SIZE is the total number of directors on boards; B_INDEP is the proportion of independen directors on boards= Total number of independent on boards/ Total number of directors on boards; CEO DUALITY is a dummy variable that takes the value 1 if the same person serves simultaneously as CEO and President of the board and 0, otherwise; FEM DIR is the Proportion of female directors on boards= Total number of female directors on boards/Total number of directors no boards; B COMPENSATION is the log of (he Pro assets over firms

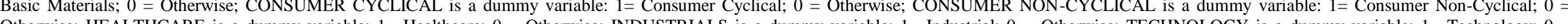
Otherwise, HEALTHCARE is a dummy variable. $1=$ Healthcare, $0=$ Otherwise; INDUSTRIALS is a dummy variable: $1=$ Industrial; $0=$ Otherwise, TECHNOLOGY is a dummy variable: $1=$ Technology; $0=$ Otherwise; TELECOMMUNICATION SERVICES is a dummy variable: $1=$ Telecommunication Services; $0=$ Otherwise and UTILITIES is a dummy variable: $1=$ Utilities; $0=$ Otherwise. AFRICA is a dummy variable: $1=$ If the country is in Africa; $0=$ Otherwise; ASIA is a dummy variable: $1=$ If the country is in Asia; $0=$ Otherwise; EUROPE is a dummy variable: $1=$ If the country is in Europe; $0=$ Otherwise; LATINAMERICA is a dummy variable: $1=$ If the country is in Latin America; $0=$ Otherwise; NORTHAMERICA is a dummy variable: $1=$ If the country is in North America; $0=$ Otherwise; OCEANIA is a dummy variable: $1=$ If the country is in Oceania; $0=$ Otherwise. $*$ p-value $<0.1 * *$ p-value $<0.05 * * *$ p-value $<0.01$. 
Table 9

Multivariate analysis results with ROE as dependent variable

\begin{tabular}{|c|c|c|c|c|c|c|}
\hline & $\begin{array}{c}\text { Model } 1 \\
\text { Coef. } \\
P>|\mathbf{t}|\end{array}$ & $\begin{array}{c}\text { Model } 2 \\
\text { Coef. } \\
P>|t|\end{array}$ & $\begin{array}{c}\text { Model } 3 \\
\text { Coef. } \\
P>|t|\end{array}$ & $\begin{array}{c}\text { Model } 4 \\
\text { Coef. } \\
P>|t|\end{array}$ & $\begin{array}{c}\text { Model } 5 \\
\text { Coef. } \\
P>|t|\end{array}$ & $\begin{array}{c}\text { Model } 6 \\
\text { Coef. } \\
P>|t|\end{array}$ \\
\hline B_SIZE & $\begin{array}{c}0.005^{* * * *} \\
(0.000)\end{array}$ & & & & & $\begin{array}{c}0.026^{* *} \\
(0.010)\end{array}$ \\
\hline B_INDEP & & $\begin{array}{l}0.062^{* *} \\
(0.000)\end{array}$ & & & & $\begin{array}{c}0.0419 * * * \\
(0.000)\end{array}$ \\
\hline CEO_DUALITY & & & $\begin{array}{c}0.798 * * * \\
(0.001)\end{array}$ & & & $\begin{array}{c}0.705 * * * \\
(0.005)\end{array}$ \\
\hline FEM_DIR & & & & $\begin{array}{c}0.115 * * * \\
(0.000)\end{array}$ & & $\begin{array}{c}0.095 * * \\
(0.000)\end{array}$ \\
\hline B_COMPENSATION & & & & & $\begin{array}{c}0.211 * * * \\
(0.000)\end{array}$ & $\begin{array}{c}0.148 * * * \\
(0.000)\end{array}$ \\
\hline B_MEETING & $\begin{array}{c}-0.150^{* * * *} \\
(0.000)\end{array}$ & $\begin{array}{c}-0.158^{* * * *} \\
(0.000)\end{array}$ & $\begin{array}{c}-0.147 * * * * \\
(0.000)\end{array}$ & $\begin{array}{c}-0.156^{* * * *} \\
(0.000)\end{array}$ & $\begin{array}{c}-0.161 * * * * \\
(0.000)\end{array}$ & $\begin{array}{c}-0.166^{* * * *} \\
(0.000)\end{array}$ \\
\hline SIZE & $\begin{array}{c}-.189^{* * * *} \\
(0.009)\end{array}$ & $\begin{array}{c}-.226 * * * \\
(0.002)\end{array}$ & $\begin{array}{c}-.201 * * * \\
(0.005)\end{array}$ & $\begin{array}{c}-.232 * * * \\
(0.001)\end{array}$ & $\begin{array}{c}-.214 * * * \\
(0.003)\end{array}$ & $\begin{array}{c}-.270 * * * \\
(0.009)\end{array}$ \\
\hline LEVERAGE & $\begin{array}{c}-0.000^{* * * *} \\
(0.003)\end{array}$ & $\begin{array}{c}-0.000 * * * * \\
(0.005)\end{array}$ & $\begin{array}{c}-0.000^{* * * *} \\
(0.002)\end{array}$ & $\begin{array}{c}-0.000 * * * * \\
(0.002)\end{array}$ & $\begin{array}{c}-0.000 \text { **** } \\
(0.003)\end{array}$ & $\begin{array}{c}-0.000^{* * * *} \\
(0.002)\end{array}$ \\
\hline CAPITAL_INTENSITY & $\begin{array}{c}0.058^{* * *} \\
(0.014)\end{array}$ & $\begin{array}{c}0.067 * * * * \\
(0.004)\end{array}$ & $\begin{array}{c}0.057 * * \\
(0.015)\end{array}$ & $\begin{array}{c}0.075^{*} * * \\
(0.001)\end{array}$ & $\begin{array}{c}0.056^{* *} \\
(0.017)\end{array}$ & $\begin{array}{c}0.076^{* * *} * \\
(0.001)\end{array}$ \\
\hline OWNSHIP_CON & $\begin{array}{c}0.038 * * * \\
(0.000)\end{array}$ & $\begin{array}{c}0.033^{* * *} * \\
(0.001)\end{array}$ & $\begin{array}{c}0.039 * * * \\
(0.000)\end{array}$ & $\begin{array}{c}0.043 * * * \\
(0.000)\end{array}$ & $\begin{array}{c}0.034 * * * \\
(0.000)\end{array}$ & $\begin{array}{c}0.039 * * * \\
(0.000)\end{array}$ \\
\hline DUAL_CLASS & $\begin{array}{c}-1.258^{* * * *} \\
(0.000)\end{array}$ & $\begin{array}{c}-989 * * * \\
(0.005)\end{array}$ & $\begin{array}{c}-1.260 \text { *** } \\
(0.000)\end{array}$ & $\begin{array}{c}-1.433^{* * * *} \\
(0.000)\end{array}$ & $\begin{array}{c}-1.283^{* * * *} \\
(0.000)\end{array}$ & $\begin{array}{c}-1.171^{* * * *} \\
(0.001)\end{array}$ \\
\hline OPERATING_PERFORM & $\begin{array}{c}0.429 * * * \\
(0.000)\end{array}$ & $\begin{array}{c}0.427 * * * \\
(0.000)\end{array}$ & $\begin{array}{c}0.428^{* * * *} \\
(0.000)\end{array}$ & $\begin{array}{c}0.428 * * * \\
(0.000)\end{array}$ & $\begin{array}{c}0.426 * * * \\
(0.000)\end{array}$ & $\begin{array}{c}0.425 * * * \\
(0.000)\end{array}$ \\
\hline BASIC MATERIALS & $\begin{array}{c}2.909^{* * * *} \\
(0.000)\end{array}$ & $\begin{array}{c}2.875 * * * \\
(0.000)\end{array}$ & $\begin{array}{c}2.965^{* * * *} \\
(0.000)\end{array}$ & $\begin{array}{c}3.445^{* * * *} \\
(0.000)\end{array}$ & $\begin{array}{c}3.060 * * * \\
(0.000)\end{array}$ & $\begin{array}{c}3.419 * * * \\
(0.000)\end{array}$ \\
\hline CONSUMER CYCLICAL & $\begin{array}{c}6.370 * * * \\
(0.000)\end{array}$ & $\begin{array}{c}6.553 * * * \\
(0.000)\end{array}$ & $\begin{array}{c}6.380 * * * * \\
(0.000)\end{array}$ & $\begin{array}{c}6.488 * * * \\
(0.000)\end{array}$ & $\begin{array}{c}6.447 \text { **** } \\
(0.000)\end{array}$ & $\begin{array}{c}6.587 * * * \\
(0.000)\end{array}$ \\
\hline CONSUMER NON-CYCLICAL & $\begin{array}{c}8.420 * * * \\
(0.000)\end{array}$ & $\begin{array}{c}8.561 * * * \\
(0.000)\end{array}$ & $\begin{array}{c}8.438 * * * \\
(0.000)\end{array}$ & $\begin{array}{c}8.278 * * * \\
(0.000)\end{array}$ & $\begin{array}{c}8.376^{* * * *} \\
(0.000)\end{array}$ & $\begin{array}{c}8.330 * * * * \\
(0.000)\end{array}$ \\
\hline ENERGY & $\begin{array}{c}2.679 * * * \\
(0.000)\end{array}$ & $\begin{array}{c}2.538 * * * \\
(0.000)\end{array}$ & $\begin{array}{c}2.699 * * * \\
(0.000)\end{array}$ & $\begin{array}{c}3.248 * * * \\
(0.000)\end{array}$ & $\begin{array}{c}2.683 * * * \\
(0.000)\end{array}$ & $\begin{array}{c}3.007 * * * * \\
(0.000)\end{array}$ \\
\hline HEALTHCARE & $\begin{array}{c}4.762 * * * \\
(0.000)\end{array}$ & $\begin{array}{c}4.5692 * * * \\
(0.000)\end{array}$ & $\begin{array}{c}4.745^{* * * *} \\
(0.000)\end{array}$ & $\begin{array}{c}4.983 * * * \\
(0.000)\end{array}$ & $\begin{array}{c}4.799 * * * \\
(0.000)\end{array}$ & $\begin{array}{c}4.750 \text { **** } \\
(0.000)\end{array}$ \\
\hline INDUSTRIALS & $\begin{array}{c}6.527 * * * \\
(0.000)\end{array}$ & $\begin{array}{c}6.607 * * * \\
(0.000)\end{array}$ & $\begin{array}{c}6.521 * * * \\
(0.000)\end{array}$ & $\begin{array}{c}6.948^{* * *} * \\
(0.000)\end{array}$ & $\begin{array}{c}6.609 * * * \\
(0.000)\end{array}$ & $\begin{array}{c}6.922 * * * * \\
(0.000)\end{array}$ \\
\hline TECHNOLOGY & $\begin{array}{c}5.400 * * * \\
(0.000)\end{array}$ & $\begin{array}{c}5.251^{* * * *} \\
(0.000)\end{array}$ & $\begin{array}{c}5.438 * * * \\
(0.000)\end{array}$ & $\begin{array}{c}5.844 * * * \\
(0.000)\end{array}$ & $\begin{array}{c}5.435 * * * \\
(0.000)\end{array}$ & $\begin{array}{c}5.641 * * * * \\
(0.000)\end{array}$ \\
\hline TELECOMMUNICATION SERVICES & $\begin{array}{c}3.803 * * * \\
(0.000)\end{array}$ & $\begin{array}{c}3.923 * * * \\
(0.000)\end{array}$ & $\begin{array}{c}3.804 * * * * \\
(0.000)\end{array}$ & $\begin{array}{c}3.816^{* * * *} \\
(0.000)\end{array}$ & $\begin{array}{c}3.948^{* * * *} \\
(0.000)\end{array}$ & $\begin{array}{c}3.954 * * * \\
(0.000)\end{array}$ \\
\hline AFRICA & $\begin{array}{c}5.773 * * * \\
(0.001)\end{array}$ & $\begin{array}{c}7.573 * * * \\
(0.001)\end{array}$ & $\begin{array}{c}6.133 * * * \\
(0.000)\end{array}$ & $\begin{array}{c}5.515 * * * \\
(0.001)\end{array}$ & $\begin{array}{c}6.310 \text { **** } \\
(0.000)\end{array}$ & $\begin{array}{c}7.474 * * * \\
(0.000)\end{array}$ \\
\hline
\end{tabular}




\begin{tabular}{|c|c|c|c|c|c|c|}
\hline ASIA & $\begin{array}{c}-2.086^{* * * * *} \\
(0.000)\end{array}$ & $\begin{array}{c}1.304 * * * \\
(0.080)\end{array}$ & $\begin{array}{c}-1.928 * * * * \\
(0.000)\end{array}$ & $\begin{array}{c}-0.811 \text { *** } \\
(0.012)\end{array}$ & $\begin{array}{c}-0.670^{*} \\
(0.062)\end{array}$ & $\begin{array}{c}2.397 * * * * \\
(0.000)\end{array}$ \\
\hline EUROPE & $\begin{array}{c}1.242 * * * \\
(0.000)\end{array}$ & $\begin{array}{c}2.566 * * * \\
(0.000)\end{array}$ & $\begin{array}{c}1.502 * * * \\
(0.000)\end{array}$ & $\begin{array}{c}1.370 * * * \\
(0.000)\end{array}$ & $\begin{array}{c}1.369^{* * * *} \\
(0.000)\end{array}$ & $\begin{array}{c}2.531 * * * \\
(0.000)\end{array}$ \\
\hline LATINAMERICA & $\begin{array}{c}-1.933 * * \\
(0.014)\end{array}$ & $\begin{array}{c}0.617 \\
(0.459)\end{array}$ & $\begin{array}{c}-1.747 * * \\
(0.026)\end{array}$ & $\begin{array}{l}-1.047 \\
(0.178)\end{array}$ & $\begin{array}{l}-0.049 \\
(0.952)\end{array}$ & $\begin{array}{l}1.979^{*} \\
(0.020)\end{array}$ \\
\hline OCEANIA & $\begin{array}{c}0.554 \\
(0.289)\end{array}$ & $\begin{array}{c}1.209 * * \\
(0.020)\end{array}$ & $\begin{array}{l}0.894 * \\
(0.091)\end{array}$ & $\begin{array}{c}0.682 \\
(0.190)\end{array}$ & $\begin{array}{c}0.595 \\
(0.249)\end{array}$ & $\begin{array}{c}1.382^{* *} \\
(0.010)\end{array}$ \\
\hline Year effects & Yes & Yes & Yes & Yes & Yes & Yes \\
\hline $\mathrm{N}$ & 10,314 & 10,314 & 10,314 & 10,314 & 10,314 & 10,314 \\
\hline $\mathrm{R}^{2}$ & $24.31 \%$ & $24.79 \%$ & $24.38 \%$ & $25.01 \%$ & $24.71 \%$ & $25.69 \%$ \\
\hline F test & $95.31 * * *$ & $102.68 * * *$ & $95.26 * * *$ & $99.16 * * *$ & $101.93 * * *$ & $95.78 * * *$ \\
\hline
\end{tabular}

ROE ratio (return on equity), measured as the ratio of net profit over total equity; B_SIZE is the total number of directors on boards; B_INDEP is the proportion of independent directors on boards= Total number of independent on boards/ Total number of directors on boards; CEO DUALITY is a dummy variable that takes the value 1 if the same person serves simultaneously as CEO and President of the board and 0 , otherwise; FEM DIR is the Proportion of female directors on boards= Total number of female directors on boards/Total number of directors no boards; B COMPENSATION is the log of board compensation; B MEETING is the number of meetings held by boards every year; SIZE is the log of total assets; LEVERAGE is debt over total assets; CAPITAL_INTENSITY is the ratio of long-term or fixed assets over total assets; OWNSHIP_CON is the average pers is the registered/bear CONSUMER CYCLICAL is a dumy variale: 1 COn variable: $1=$ SElC SERVICES is a dummy variable: $1=$ Telecommunication Services, $0=$ Otherwise and UTILITIES is a dummy variable: $1=$ Utilities, $0=$ Otherwise. AFRICA is a dummy variable: $1=$ If the country is in Africa $0=$ Otherwise; ASIA is a dummy variable: $1=$ If the country is in Asia; $0=$ Otherwise; EUROPE is a dummy variable: $1=$ If the country is in Europe; $0=$ Otherwise; LATINAMERICA is a dummy variable: $1=$ If the country is in Latin America; $0=$ Otherwise; NORTHAMERICA is a dummy variable: $1=$ If the country is in North America; $0=$ Otherwise; OCEANIA is a dummy variable: $1=$ If the country is in Oceania; $0=$ Otherwise *p-value $<0.1 * *$ p-value $<0.05 * * *$ p-value $<0.01$ 